OPEN ACCESS

Edited by:

Yongxiang $\mathrm{Li}$,

Naniing University, China

Reviewed by:

Eric Font

University of Lisbon, Portugal

Ioan Lascu,

University of Cambridge, UK

Janna Just,

University of Cologne, Germany

*Correspondence:

Juan C. Larrasoaña,

Instituto Geológico y Minero de

España, Now Visiting Scientist at: Institute of Earth Sciences Jaume

Almera, ICTJA-CSIC, Lluís Solé i

Sabarís s/n, 08028 Barcelona, Spain jc.larra@igme.es

Specialty section:

This article was submitted to Geomagnetism and Paleomagnetism, a section of the journal Frontiers in Earth Science

Received: 04 March 2015 Accepted: 02 May 2015 Published: 29 May 2015

Citation:

Larrasoaña JC, Roberts AP, Liu Q Lyons $R$, Oldfield F, Rohling EJ and

Heslop D (2015) Source-to-sink magnetic properties of NE Saharan dust in Eastern Mediterranean marine sediments: review and

paleoenvironmental implications. Front. Earth Sci. 3:19. doi: 10.3389/feart.2015.00019

\section{Source-to-sink magnetic properties of NE Saharan dust in Eastern Mediterranean marine sediments: review and paleoenvironmental implications}

\author{
Juan C. Larrasoaña ${ }^{1,2 *}$, Andrew P. Roberts ${ }^{3}$, Qingsong Liu ${ }^{4}$, Richard Lyons ${ }^{5}$, \\ Frank Oldfield ${ }^{5}$, Eelco J. Rohling ${ }^{3,6}$ and David Heslop ${ }^{3}$ \\ ${ }^{1}$ Instituto Geológico y Minero de España, Zaragoza, Spain, ${ }^{2}$ Institute of Earth Sciences Jaume Almera, ICTJA-CSIC, \\ Barcelona, Spain, ${ }^{3}$ Research School of Earth Sciences, The Australian National University, Canberra, ACT, Australia, ${ }^{4}$ State \\ Key Laboratory of Lithospheric Evolution, Institute of Geology and Geophysics, Chinese Academy of Sciences, Beijing, \\ China, ${ }^{5}$ School of Environmental Sciences, University of Liverpool, Liverpool, UK, ${ }^{6}$ Ocean and Earth Science, National \\ Oceanography Centre, University of Southampton, Southampton, UK
}

We present a review of the magnetic properties of NE Saharan dust that was conducted, following a source-to-sink approach, to unravel the paleoclimatic significance of environmental magnetic records from Eastern Mediterranean marine sediments. Our synthesis indicates that pedogenic hematite, which formed during past wetter Green Sahara periods (GSPS), is the most common magnetic mineral in Eastern Mediterranean marine sediments as a result of its eolian transportation, along with smaller amounts of lithogenic hematite, from the NE Sahara. Coupled with the limited impact of reductive sedimentary diagenesis on hematite abundances in Eastern Mediterranean Sea sediments, this indicates that hematite concentrations provide reliable quantitative estimates of NE Saharan dust supply. Our results indicate that variations in NE Saharan dust supply record an on-off mechanism in which a key control on eolian input is provided by the monsoon-driven spread and retreat of savannah vegetation through the Sahara. Magnetite/maghemite is also a common magnetic mineral in NE Saharan dust, and also formed mainly pedogenically during GSPs but in much smaller amounts compared to hematite. Limited production of magnetite/maghemite in the source area during GSPs, along with the later imprint of diagenetic processes, indicates that magnetite/maghemite abundances cannot be used to estimate dust inputs from the NE Sahara. Goethite cannot be used either to estimate variations in NE Saharan dust supply, because its occurrence in Eastern Mediterranean marine sediments also appears to be linked to fluvial inputs. Our results reinforce the view that a source-to-sink approach should be routinely conducted in environmental magnetic studies to understand the complex combination of processes involved in the production, transportation, sedimentation, and diagenetic evolution of magnetic minerals in sedimentary environments.

Keywords: environmental magnetism, marine sediments, eolian dust, Sahara, Eastern Mediterranean Sea, hematite, magnetite, maghemite 


\section{Introduction}

About $\sim 2000 \mathrm{Mt}$ of eolian dust is emitted annually into the atmosphere mainly from subtropical deserts (Maher et al., 2010). Dust has a direct influence on Earth's climate because, once in the atmosphere, it alters the radiative balance by scattering and absorbing solar and terrestrial radiation and also because it affects cloud nucleation processes (Engelstaedter et al., 2006; Mahowald et al., 2006; Maher et al., 2010; Shao et al., 2011). In addition, eolian dust influences climate indirectly by supplying iron for phytoplankton growth in Fe-limited ocean waters, which in turn results in drawdown of atmospheric $\mathrm{CO}_{2}$ and, hence, impacts global temperatures (Prospero et al., 2002; Engelstaedter et al., 2006; Mahowald et al., 2006; Maher et al., 2010; Shao et al., 2011).

Eolian dust, moreover, is implicated in a wide range of environmental processes, including soil formation (McTainsh and Strong, 2007), fertilization of continental environments such as forests and lake systems (McTainsh and Strong, 2007), coral contamination (Shinn et al., 2000), and human health problems (Prospero et al., 2005), among others (see Field et al., 2010 for a review). In addition to being a driver of climate and ecological change, eolian dust that accumulates in different environments such as loess/paleosol sequences (Ding et al., 2002), ice cores (Bory et al., 2003), and marine sediments (Yamazaki and Ioka, 1997; Bailey et al., 2011; Roberts et al., 2011) provides an opportunity to study past climate variations and atmospheric dynamics. Understanding the past record of dust accumulation is, therefore, a timely line of research aimed at disentangling its role both as a driver and recorder of past climate change (Engelstaedter et al., 2006; Mahowald et al., 2006; Maher et al., 2010; Maher, 2011; Liu et al., 2012a).

Magnetic minerals are ubiquitous in eolian dust (Maher, 2011). Magnetic methods provide a non-invasive and timeefficient way to assess the abundance of airborne magnetic minerals in the sedimentary record. It is, therefore, not surprising that environmental magnetic methods applied to marine sedimentary sequences provide some of the most reliable records of long-term deposition of eolian dust (Liu et al., 2012a). However, interpretation of environmental magnetic records is complicated given the complex interplay of processes that govern magnetic mineral assemblages in dust-bearing sediments (Liu et al., 2012a). For example, the composition of airborne magnetic minerals might change in response to varying climatic conditions in dust source areas (Maher, 2011). Once deposited in sediments, the signal of airborne magnetic minerals can be overprinted by other detrital or biogenic sources (e.g., Hesse, 1994; Roberts et al., 2011). Moreover, loss of detrital magnetic minerals or authigenic growth of new magnetic phases can occur during sedimentary diagenesis (Hounslow and Maher, 1999; Abrajevitch and Kodama, 2011; Liu et al., 2012a; Roberts, 2015, submitted). Adequate evaluation of the reliability of magnetic minerals as recorders of eolian dust deposition, therefore, demands careful, case-specific investigation of the processes that drive the formation, transportation, accumulation and preservation of magnetic minerals in sediments (Maher, 2011; Liu et al., 2012a).

The areas that have provided the most outstanding records of eolian dust deposition based on magnetic properties are the equatorial Atlantic Ocean (Bloemendal et al., 1993; deMenocal, 1995; Maher and Dennis, 2001; Itambi et al., 2009; Just et al., 2012), the N Pacific Ocean (Doh et al., 1988; Yamazaki and Ioka, 1997; Yamazaki, 2009, 2012; Bailey et al., 2011), the eastern Mediterranean Sea (Dinarès-Turell et al., 2003; Larrasoaña et al., 2003a; Köhler et al., 2008; Liu et al., 2012b), the Arabian Sea (Bloemendal and deMenocal, 1989; deMenocal et al., 1991; Bloemendal et al., 1993; deMenocal, 1995; Hounslow and Maher, 1999), and the Red Sea (Rohling et al., 2008; Roberts et al., 2011) (for a review see Maher, 2011). Given the often discontinuous nature of the continental sedimentary record, these marine magnetic records of eolian dust deposition provide valuable sources of information on past climate variability in continental regions (Liu et al., 2012a). In the case of the Eastern Mediterranean Sea, magnetic records of eolian dust deposition have been used to provide novel information on paleo-environmental conditions in the neighboring Sahara Desert (Larrasoaña et al., 2003a; Köhler et al., 2008), which has important implications for better understanding paleo-monsoon dynamics (Trauth et al., 2009) and of any climatic influence on human evolution (Larrasoaña et al., 2013).

In this paper, we thoroughly examine the significance of Eastern Mediterranean magnetic records of Saharan dust deposition by providing an overview of the magnetic properties of dust, following a source-to-sink approach that extends from rock units that crop out in the NE Saharan source area to the depositional sink of dust in the Eastern Mediterranean Sea, including intermediate pathways (surface sediments and dust). This information is combined with a synthesis of climate and paleoclimate data, which provides information on presentday and past weathering regimes in the source areas. This approach provides the basis for identifying magnetic minerals that are present in dust, the climatic conditions under which they originated, and whether they are able to carry a reliable signal of eolian dust supply once deposited in the deep sea.

\section{The NE Saharan-Eastern Mediterranean Dust System}

\section{Geological Setting}

The NE Sahara (NES) is the portion of the Sahara located between 20 to $30^{\circ} \mathrm{N}$ and 15 to $30^{\circ} \mathrm{E}$ that includes most of eastern Libya, western Egypt and northern Chad and Sudan (Figure 1). The geology of the NES is characterized by a Precambrian basement that belongs to the African and ArabianNubian shields (see Schlüter, 2008). This basement crops out along the Red Sea coast, in the Tibesti Massif, and in the Jebel Uweinat region, and includes a wide variety of sedimentary, metamorphic, volcanic and igneous rocks with ages that range between Mesoarchaean to Neoproterozoic. Precambrian rocks from the Tibesti and Jebel Uweinat massifs are surrounded by thick (some thousands of meters) Paleozoic sedimentary units that also include volcanic, metamorphic, and intrusive rocks. Mesozoic rocks include Triassic and Jurassic sedimentary sequences that are mainly represented by Upper Jurassic to Upper Cretaceous continental and marine sedimentary rocks, 


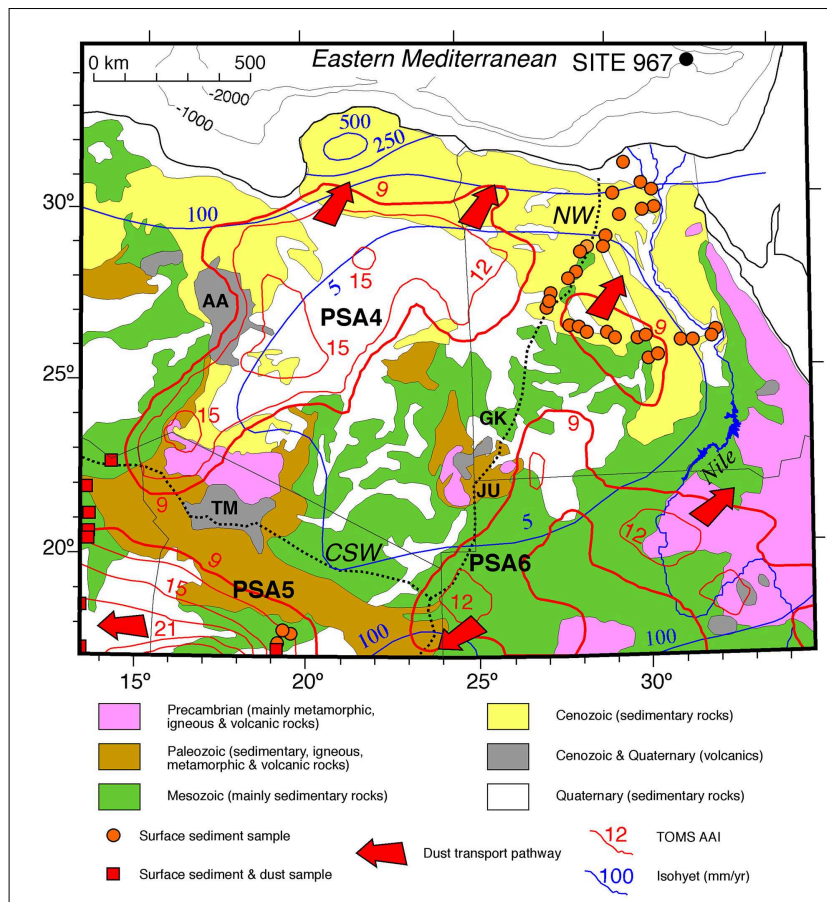

FIGURE 1 | Geological sketch map of the NE Sahara, with indication of mean annual precipitation (blue contours; Petit-Maire and Guo, 1997), total ozone mapping spectrometer (TOMS) annual aerosol index (red contours; Goudie and Middleton, 2001), preferential dust source areas (PSAs, Scheuvens et al., 2013) and the main paths for eolian dust transportation (red arrows; Trauth et al., 2009; Varga et al., 2014). Orange circles indicate the locations of surface sediment samples studied by Lyons et al. (2010), and red squares indicate the locations of surface sediment and dust samples studied by Lyons et al. (2012) and Oldfield et al. (2014). AA, Al-Haruj al-Aswad massif; TM, Tibesti massif; JU, Jebel Uweinat; GK, Gilf Kebir; CSW, central Saharan watershed; NW, Nile watershed.

respectively, that crop out throughout most of the southern fringe of the NES with thicknesses of up to $4000 \mathrm{~m}$ (Figure 1). Mesozoic rocks are overlain by Paleogene sedimentary sequences that accumulated mainly in shallow marine environments, and which increase in thickness toward the north to a maximum of about $1000 \mathrm{~m}$ (Swezey, 2009). Neogene strata include continental sediments that grade toward the north to shallow marine sediments, with a maximum thickness of up to $500 \mathrm{~m}$ throughout most of the NES (Swezey, 2009). The Quaternary in the region is represented by discontinuous and thin (a few meters thick) outcrops of lacustrine carbonates and mudstones, distal alluvial and playa sediments, and sand seas and sheets, which mainly occupy lowlands. Volcanic activity throughout the Cenozoic and Quaternary is responsible for volcanic rocks and associated tectonic uplift, mainly in the Tibesti and Al-Haruj al-Aswad massifs (Figure 1).

The NES includes a preferential dust source area (PSA), which has been identified using a variety of complementary methods, from where Saharan dust largely emanates (Scheuvens et al., 2013). This area (PSA4) extends throughout the northern slopes of the Tibesti Massif into the lowlands of eastern Libya and western Egypt, and is best delineated by the Total Ozone Mapping Spectrometer (TOMS) annual aerosol index (Figure 1).
PSA4 includes Quaternary alluvial and lake sediments, modern wadi systems sourced in the Tibesti, Al-Haruj al-Aswad and Gilf Kebir massifs, and large sand seas. The easily weathered and deflated silt and clay-rich sediments in this region (Goudie and Middleton, 2001; Prospero et al., 2002), along with additional fine-grained material produced by eolian abrasion of sand in sand seas (Crouvi et al., 2012), fuel dust production. PSA4 constitutes the main source area for dust transported into the Eastern Mediterranean Sea, which occurs mainly in spring and early summer in connection with the passage of Mediterranean and Sharav cyclones (Goudie and Middleton, 2001; Varga et al., 2014). Throughout the rest of the year, predominant trade winds transport dust from PSA4 to the south and west. Dust that emanates from more southerly source areas (e.g., PSA5: Bodelé depression and PSA6: north Sudan, Scheuvens et al., 2013) is mainly transported to the west and south (Figure 1). NES dust transported by Mediterranean and Sharav cyclones takes 2-4 days to reach the central part of the Eastern Mediterranean Sea (Goudie and Middleton, 2001), and an additional 8-16 days to reach the seafloor of Eastern Mediterranean deep basins (according to mean settling velocities of 220-240 $\mathrm{md}^{-1}$, Lee et al., 2009), where it accumulates. Overall, the journey of eolian dust from its source in the NES to its sink in Eastern Mediterranean deep basins is $\sim 10$ to 20 days.

\section{Climatic and Paleoclimatic Context}

The NES is located below the descending branch of the northern hemisphere Hadley cell, which brings warm and dry air masses that are responsible for high temperatures, minimal rainfall, and prevailing clear skies and windy (NE trades) conditions (Laity, 2008). Rare precipitation events in the southernmost fringe of the NES are linked to penetration of SW monsoon winds during the northern hemisphere summer, when enhanced insolation over the tropics drives convective rainfall along the intertropical convergence zone (ITCZ) (Gasse, 2000). In the northernmost NES, rainfall is linked to the passage of midlatitude cyclones during northern hemisphere winter, which reach the Sahara when the ITCZ is at its southernmost position (Gasse, 2000). As a result of this climatic context, precipitation in the NES is less than $100 \mathrm{~mm} /$ year at distances of 100-200 $\mathrm{km}$ from the Mediterranean coast and north of $\sim 18^{\circ} \mathrm{N}$, with virtually no rainfall (i.e., $<5 \mathrm{~mm}$ /year) throughout most of the NES (Figure 1) (Petit-Maire and Guo, 1997). These harsh arid conditions, modulated by topographic features, drive weathering mainly associated with daily insolation changes and with the presence of moisture, salt, and dust near the rock surface (Laity, 2008). Weathered material is eventually removed by hillslope processes and by sporadic rains, which transport the material into the lowlands through ephemeral streams. In the lowlands, wind action reworks the material, which leads to dust export and formation of sand accumulations (Prospero et al., 2002; Maher et al., 2010). Soils are poorly developed and restricted to leptosols that formed over rocky substrates in highlands and to calcisols, arenosols, and gypsisols that developed over unconsolidated alluvial, playa and eolian sediments in lowlands (Food and Agriculture Organization of the United Nations et al., 2009; Crouvi et al., 2012). 
Variations on this general picture occur as a result of climatic changes. For example, short-lived (e.g., 4-8 kyr) past periods of increased monsoonal precipitation in the Sahara, called "green Sahara" periods (GSPs), led to development of lakes and permanent river systems and to the spread of savannah vegetation through the NES (Kuper and Kröpelin, 2006; Drake et al., 2011; Lézine et al., 2011; Larrasoaña et al., 2013). Paleoprecipitation estimates for the Holocene ( 6-11 $\mathrm{ka})$ and Eemian ( 121-128 ka) GSPs, which can be taken as representative of late Pleistocene-Holocene GSPs, indicate mean annual precipitations of around 100-300 mm/year (Kuper and Kröpelin, 2006; Larrasoaña et al., 2013) and 400-600 mm/year (Kowalski et al., 1989; Kieniewicz and Smith, 2009; Larrasoaña et al., 2013) throughout the core of the NES, respectively. Wetter conditions may have prevailed during earlier GSPs (Drake et al., 2008; Geyh and Thiedig, 2008; Larrasoaña et al., 2013). It is the fine-grained material transported by rivers from the highlands to the lowlands during GSPs, which accumulated in distal alluvial and lacustrine settings, that fuels the bulk of dust produced during subsequent hyper-arid desert phases (Prospero et al., 2002; Maher et al., 2010). During peak glacial periods, such as the Last Glacial Maximum, colder and wetter conditions prevailed in the highest parts of the Saharan mountains such as the Tibesti Massif, whereas hyper-arid conditions prevailed in the neighboring lowlands (Maley, 2000). Given that the main source areas for NES dust are the lowlands of Libya and Egpyt, the impact of Pleistocene glacial conditions on dust formation can be considered minimal compared to that of GSPs.

\section{Source-to-Sink Magnetic Properties of NE Saharan Dust}

\section{Rocks}

Magnetic properties of rocks that crop out within and around PSA4 have been mainly used to assess the origin of paleomagnetic components identified in paleomagnetic studies. Magnetite is ubiquitously present in a wide range of volcanic rocks ranging from Precambrian (Reischmann et al., 1992), to Paleozoic (Bachtadse and Briden, 1991), Mesozoic (Lotfy, 2011), and Cenozoic (Hussain and Aziz, 1983; Perrin et al., 2009) in age, and also in igneous, metamorphic, and sedimentary rocks that range in age from Proterozoic (Reischmann et al., 1992) to Paleozoic (Davies et al., 1980) and Mesozoic (Hussain and Aziz, 1983). Magnetite is also the dominant magnetic mineral in Paleogene (Lotfy and van der Voo, 2007), Neogene (Abdeldayem, 1996; Lean et al., 1998), and Quaternary (Lean et al., 1998) sedimentary rocks. Hematite is reported less frequently than magnetite, but still dominates the magnetic mineral assemblages in some Precambrian (Davies et al., 1980), Paleozoic (Bachtadse and Briden, 1991) and Mesozoic (Lotfy, 2011) volcanic rocks and also in sedimentary rocks that range in age from Mesozoic to Quaternary (Hussain and Aziz, 1983; Abdeldayem, 1996, 1999; Lean et al., 1998; Odah, 2004; Lotfy and van der Voo, 2007; Lotfy, 2011). Some of these rocks, such as the Nubian Mesozoic sandstones (Odah, 2004) and some Paleogene and Neogene formations (Abdeldayem, 1999) also contain smaller amounts of magnetite.
Goethite has been reported as the main magnetic mineral in some Precambrian (Davies et al., 1980) and Paleozoic (Bachtadse and Briden, 1991) volcanic rocks, as well as in some Mesozoic (Lotfy, 2011), Paleogene (Lotfy and van der Voo, 2007) and Neogene (Abdeldayem, 1996, 1999) sedimentary rocks. Maghemite has been reported only in Paleozoic volcanic rocks (Bachtadse and Briden, 1991). We are unaware of any rock from the region in which magnetic iron sulfides such as greigite or pyrrhotite have been reported although the former might be present in some sedimentary rocks with lacustrine or marine origins and the latter could also be present in metamorphic rocks (Horng and Roberts, 2006; Liu et al., 2012a).

Of the main magnetic minerals discussed above, it is worth noting that goethite has been interpreted to form under present-day weathering conditions in Miocene and Quaternary sedimentary rocks from the Qattara depression (Abdeldayem, 1996) and the Red Sea coast, where hematite might also be forming during weathering (Lean et al., 1998). Hematite and maghemite that formed during recent weathering have been reported from Paleozoic volcanic rocks from northern Sudan (Bachtadse and Briden, 1991).

\section{Surface Sediments}

Magnetic property data for 103 surface materials exist for the easternmost part of PSA4 in Egypt, the Chad basin (PSA5) and for other dust source areas in Mali (Lyons et al., 2010, 2012; Oldfield et al., 2014) (Figure 1). These surface materials include recent (e.g., Quaternary) distal alluvial and lacustrine sediments as well as soil and dune sands. They are, therefore, expected to represent different weathering stages that range between nearly unaltered (e.g., recent alluvial sediments) to more mature (e.g., soils and dune sands). Soils and sands are dominated by coarsegrained material (e.g., $>80 \%$ by weight has sizes $>63 \mu \mathrm{m}$ ), with modal grain sizes similar to those of soils (100 and $300 \mu \mathrm{m}$, O'Hara et al., 2006) and sand dunes (100-300 $\mu \mathrm{m}$, Junge, 1979; Besler, 2000) in the region. Grain size data for distal alluvial and lacustrine sediments are not available, but they are expected to be enriched in the clay and silt (e.g., $<63 \mu \mathrm{m}$ ) fractions (Smalley et al., 2005). The magnetic mineral assemblage of these surface sediments is characterized by the presence of both low and high coercivity magnetic minerals, which are dominantly associated with the fine grain-size fraction (e.g., silt and clay) (Lyons et al., 2010, 2012; Oldfield et al., 2014). The low coercivity fraction corresponds to a ferromagnetic mineral whose size spans the superparamagnetic/stable single domain (SP/SD) boundary, regardless of variable background lithologies and climatic context (Lyons et al., 2010, 2012; Oldfield et al., 2014). Rock magnetic data are consistent with the presence of both magnetite and maghemite, but do not enable a clear distinction between these minerals. Nevertheless, the concentration of ferrimagnets (estimated from the anhysteretic remanent magnetization, ARM) increases tenfold between arid regions of the central Sahara (e.g., $<25 \mathrm{~mm} /$ year) and wetter regions ( $>800 \mathrm{~mm} /$ year) further to the south (Figure 2A) (Lyons et al., 2010). Coarser [pseudosingle domain (PSD) and multi-domain (MD)] ferrimagnetic grains are also found in soils and dune sands (Lyons et al., 2010, 2012; Oldfield et al., 2014). The high coercivity fraction is dominated by hematite. Hematite concentration (inferred from 

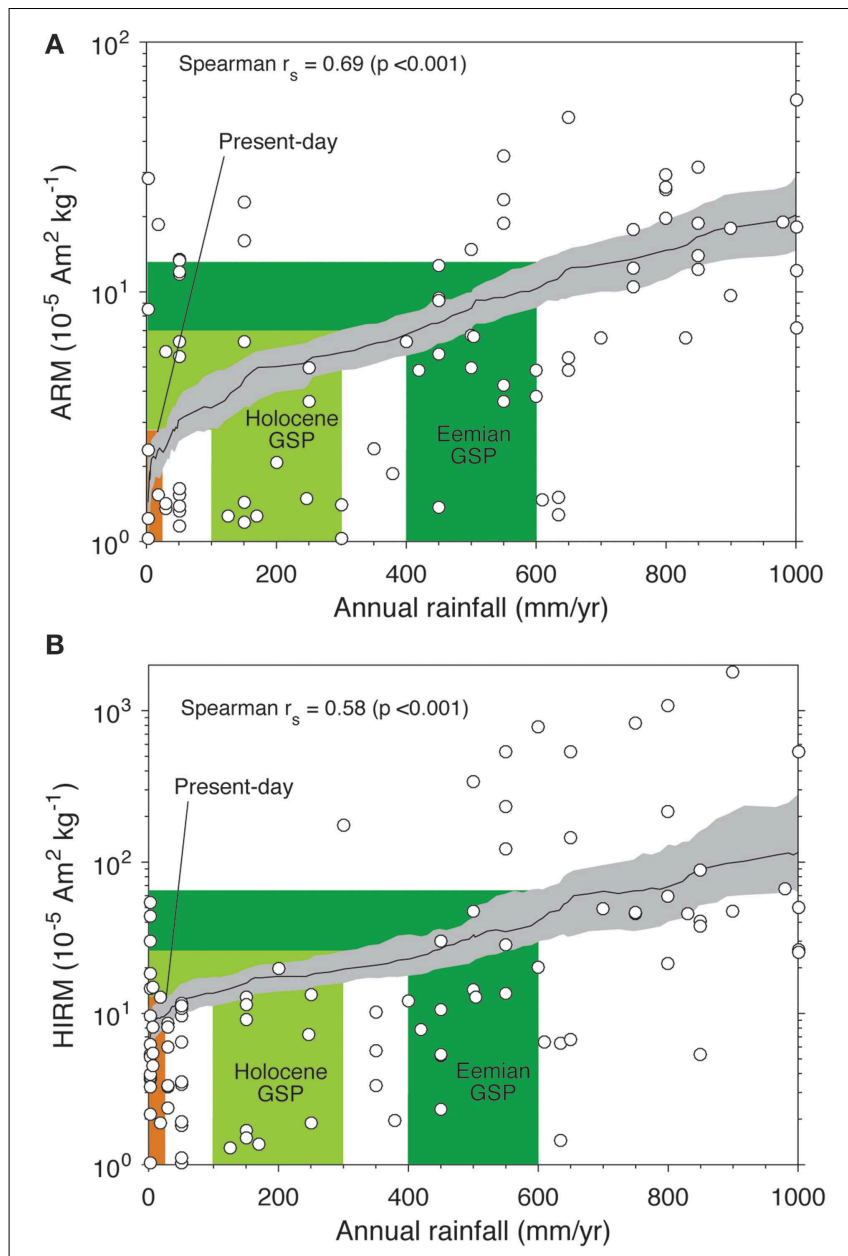

FIGURE 2 | Variations in (A) ARM values (proxy for the concentration of pedogenic magnetite/maghemite) and (B) HIRM values (proxy for the concentration of pedogenic hematite) of Saharan surface sediments as a function of precipitation. Both $\mathrm{ARM}$ and $\mathrm{HIRM}$ exhibit a significant Spearman rank correlation with precipitation. The black lines indicate the best fits calculated following a nonparametric regression based on the rank transform of Conover and Iman (1981). The shaded regions are the 95\% confidence intervals for the regressions. Orange, light green and dark green fields indicate the range of precipitation and associated ARM and HIRM values associated with present-day, Holocene GSP and Eemian GSP conditions, respectively.

the hard isothermal remanent magnetization (HIRM) imparted with a field of $1 \mathrm{~T}$ and a back field of $300 \mathrm{mT}$ ) increases more than tenfold when precipitation rises from $<25$ to $>800 \mathrm{~mm} /$ year (Figure 2B), and its coercivity increases with decreasing rainfall (Lyons et al., 2010). Goethite might also be present in a minority of samples (Oldfield et al., 2014). The average HIRM of surface sediments $\left(84.27 \pm 24.3 \times 10^{-5} \mathrm{Am}^{2} \mathrm{~kg}^{-1}\right)$ is about 10 times larger than the average ARM $\left(8.1 \pm 1 \times 10^{-5} \mathrm{Am}^{2} \mathrm{~kg}^{-1}\right)$ for the same sediments (Lyons et al., 2010).

\section{Dust}

Magnetic property data are available for 41 local dust samples collected as sweepings from buildings and exposed surfaces from the southernmost sector of PSA4 in Niger and from PSA5 in Niger and Chad, including some locations where surface sediments were also sampled (Figure 1) (Lyons et al., 2012; Oldfield et al., 2014). Although no modal grain sizes are reported for these dust samples, they are expected to have modal sizes comparable to those of other local dust samples from central Libya (e.g., 90-100 $\mu \mathrm{m}$, Smalley et al., 2005; O’Hara et al., 2006). Dust samples have magnetic properties that broadly mimic those of surface sediments from the same region (Lyons et al., 2012; Oldfield et al., 2014). Thus, the silt and clay fraction of dust samples is dominated by hematite and fine-grained ferrimagnetic grains, whose concentrations broadly increase as a function of precipitation (Lyons et al., 2012; Oldfield et al., 2014). The coarser fraction of dust samples also includes coarser (PSD and MD) ferrimagnetic grains. Average HIRM values of dust $65.74 \pm$ $9.15 \times 10^{-5} \mathrm{Am}^{2} \mathrm{~kg}^{-1}$ ) are 2.11 times those of ARM values $\left(31.08 \pm 3.75 \times 10^{-5} \mathrm{Am}^{2} \mathrm{~kg}^{-1}\right)$ for the same samples (Lyons et al., 2012). When a direct comparison can be made, the concentration of both hematite and ferrimagnets is significantly larger (e.g., 15 and 10 times, respectively) in dust samples than in surface sediments (Oldfield et al., 2014).

The only published rock magnetic data for Eastern Mediterranean regional dust samples which we are aware are magnetic susceptibility data from atmospheric particulates collected in $0.5-\mu \mathrm{m}$ nylon meshes on board scientific cruises (Chester et al., 1984). Although no grain size data were reported for these dust samples, they are expected to have a modal grain size similar to that of regional NES dust collected at Crete (8-30 $\mu \mathrm{m}$, Mattsson and Nihlén, 1996) and Israel (20-40 $\mu \mathrm{m}$, Yaalon and Ganor, 1979). Unpublished ARM and HIRM results from this dataset point to the occurrence of both ferrimagnets and hematite in the studied samples. Although the data are limited (5 samples), mean HIRM $\left(79.6 \pm 3.99 \times 10^{-5} \mathrm{Am}^{2} \mathrm{~kg}^{-1}\right)$ and ARM $\left(20.91 \pm 2.06 \times 10^{-5} \mathrm{Am}^{2} \mathrm{~kg}^{-1}\right)$ values of these regional dust samples, as well as their ratio (3.81), are similar to those of local dust samples (Lyons et al., 2012).

\section{Marine Sediments}

The deep basins of the Eastern Mediterranean Sea are characterized by thick (several tens of $\mathrm{m}$ ) sequences of gray, yellow, brownish and reddish hemipelagic nannofossil oozes (referred to here as background sediments) with low organic carbon contents ( $<0.5 \%$ by weight) (Wehausen and Brumsack, 1999, 2000; Emeis et al., 2000). Interbedded within these background sediments are thin (typically $<20 \mathrm{~cm}$ ) sapropel layers, which have dark colors associated with their elevated organic carbon contents (typically $2-10 \%$ and up to $30 \%$ ) (Wehausen and Brumsack, 1999, 2000; Emeis et al., 2000). Sapropels mark peak humid conditions associated with GSPs; their formation is, therefore, linked to periods of enhanced monsoonal precipitation driven by boreal summer insolation maxima associated with precession minima (Hilgen et al., 1995; Emeis et al., 2000; Wehausen and Brumsack, 2000; Larrasoaña et al., 2013; Rohling et al., 2015) (Figure 3). Due to the impact of eccentricity modulation of insolation on monsoon variability, sapropels (and hence GSPs) tend to cluster around 400- and 100-kyr eccentricity maxima (Hilgen et al., 1995; Emeis et al., 2000; Wehausen and Brumsack, 2000; Larrasoaña 


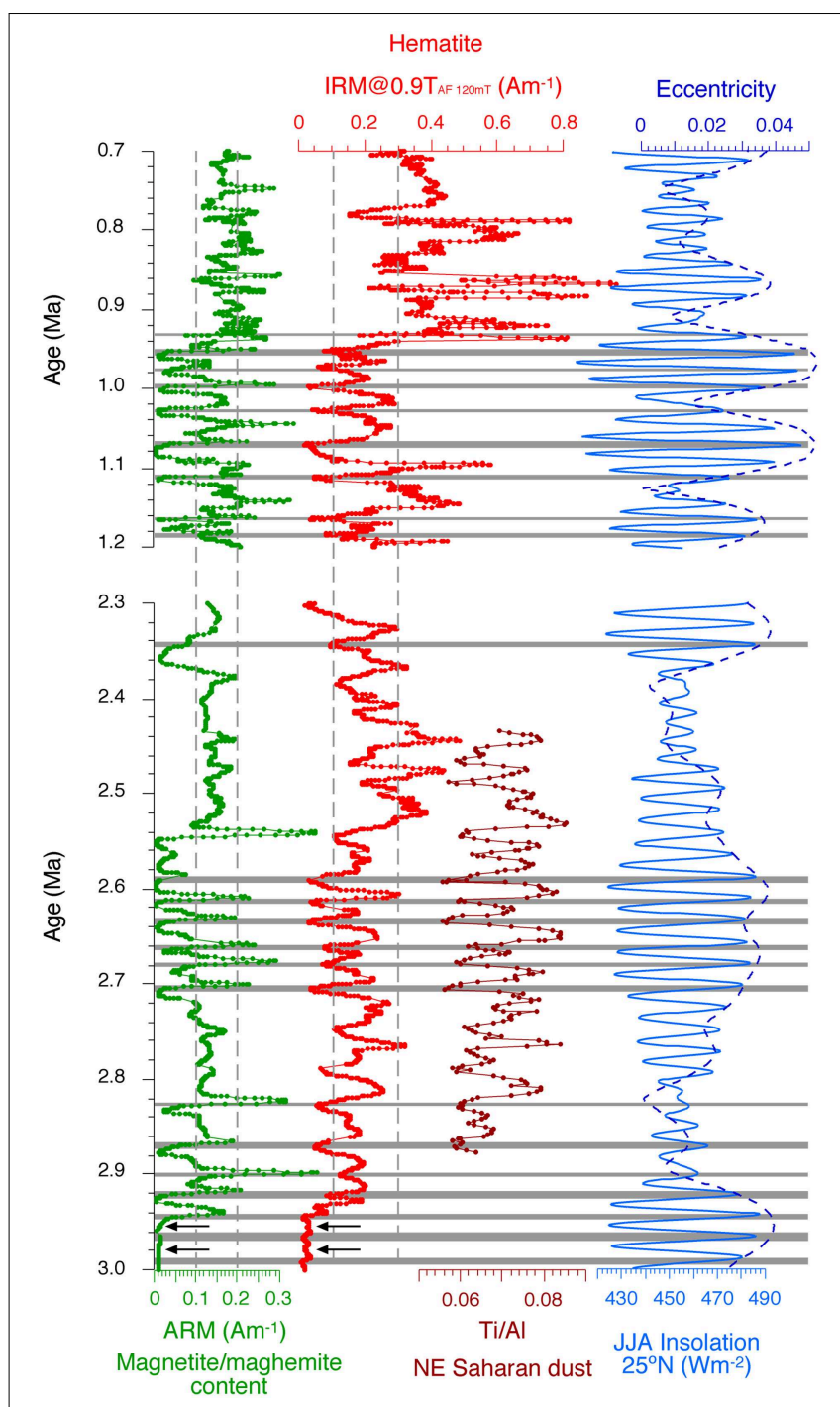

FIGURE 3 | Variations of ARM (proxy for magnetite/maghemite) and IRM@AF (proxy for hematite) through selected time intervals from Ocean Drilling Program Site 967. Gray bars indicate the positions of sapropels, and black arrows indicate the positions of extremely sulphidic sapropels. ARM and IRM@AF data are from Larrasoaña et al. (2003a,b), and Ti/Al data are from Wehausen and Brumsack (2000).

et al., 2013; Rohling et al., 2015). Sedimentation during 400and 100-kyr eccentricity minima was associated with the lowest amplitude variations of boreal summer insolation, which prevented enhanced monsoonal precipitation and sapropel formation (Hilgen et al., 1995; Emeis et al., 2000; Wehausen and Brumsack, 2000; Trauth et al., 2009; Larrasoaña et al., 2013; Rohling et al., 2015).

The terrigenous fraction of Eastern Mediterranean marine sediments is about $30-40 \%$ of the total sediment, and eolian dust typically constitutes $65-95 \%$ of the total terrigenous sediment fraction (Lourens et al., 2003). This indicates that the total fraction of NES dust in Eastern Mediterranean marine sediments can be estimated at 15-35\%. End-member analyses of grain size data for sediments from off the Israel coast indicate that the modal grain size of NES eolian dust is about $40 \mu \mathrm{m}$ (Hamann et al., 2008), which is similar to the modal size of modern dust collected at Crete $(8-30 \mu \mathrm{m}$, Mattsson and Nihlén, 1996) and Israel (20-40 $\mu \mathrm{m}$, Yaalon and Ganor, 1979) at a similar downwind distance from its NES source area.

Magnetic data indicate that a common magnetic mineral in Eastern Mediterranean marine sediments is magnetite, the abundance of which is best assessed using ARM data (Van Santvoort et al., 1997; Roberts et al., 1999; Kruiver and Passier, 2001; Passier et al., 2001; Passier and Dekkers, 2002; Larrasoaña et al., 2003b, 2006, 2008; Liu et al., 2012b). ARM values, and hence magnetite abundances, are lowest $\left(<0.05 \mathrm{Am}^{-1}\right)$ within the lower parts of sapropels and down to $50 \mathrm{~cm}$ below them (Figure 3). ARM values are highest $\left(0.2-0.4 \mathrm{Am}^{-1}\right)$ up to $20 \mathrm{~cm}$ above sapropels, thereby indicating that magnetite concentration peaks at those positions (Van Santvoort et al., 1997; Kruiver and Passier, 2001; Passier et al., 2001; Passier and Dekkers, 2002; Larrasoaña et al., 2003b, 2006, 2008; Liu et al., 2012b). ARM values that range between 0.1 and $0.2 \mathrm{Am}^{-1}$ characterize most background sediments, whether intercalated between sapropels around eccentricity maxima or within thick sapropel-barren intervals near eccentricity minima. These values indicate subtle magnetite concentration variations in background sediments (Figure 3). Magnetic data indicate that hematite is also ubiquitous in Eastern Mediterranean Sea sediments (Kruiver and Passier, 2001; Larrasoaña et al., 2003b, 2006, 2008; Balsam et al., 2007; Köhler et al., 2008), as has also been shown by diffuse reflectance spectroscopy (DRS) data (Heslop et al., 2007; Liu et al., 2012b). Hematite abundances are typically inferred using HIRM or other properties aimed at isolating high-coercivity mineral signals (e.g., an alternating field-demagnetized IRM or IRM@AF) (Larrasoaña et al., 2003b, 2006, 2008; Liu et al., 2012b). The maximum field that can be imparted in most laboratories for IRM acquisition is around $1 \mathrm{~T}$, and the coercivity of goethite is typically larger than several (up to 57) T (Peters and Dekkers, 2003; Maher et al., 2004; Rochette et al., 2005; Maher, 2011). HIRM and IRM@AF are, therefore, practically unaffected by any goethite in sediments. IRM@AF values are lowest $(<0.05$ $\mathrm{Am}^{-1}$ ) within the central part of sapropels, hence indicating hematite abundance minima (Figure 3). Using IRM@AF values, hematite contents are significantly larger in most background sediments (e.g., 0.2-0.9 $\mathrm{Am}^{-1}$ ). Compared to magnetite, hematite concentrations appear to be significantly larger in thick sapropel-barren sequences associated with eccentricity minima than in background sediments intercalated with sapropels around eccentricity maxima (Figure 3). The only exceptions to this general pattern of ARM and IRM@AF variations are some prominent, organic-rich sapropels. The lowest magnetite and hematite contents (e.g., ARM and IRM@AF $<<0.05 \mathrm{Am}^{-1}$ ) characterize this type of sapropel and the background sediments in which they are intercalated (arrows in Figure 3).

Goethite is commonly identified in Eastern Mediterranean marine sediments. Given the practical difficulties in applying magnetic fields that can saturate goethite, identification of this mineral has largely been based on DRS data (Heslop et al., 2007; Köhler et al., 2008; Liu et al., 2012b). DRS data suggest that goethite, although ubiquitous, is less abundant than hematite in 


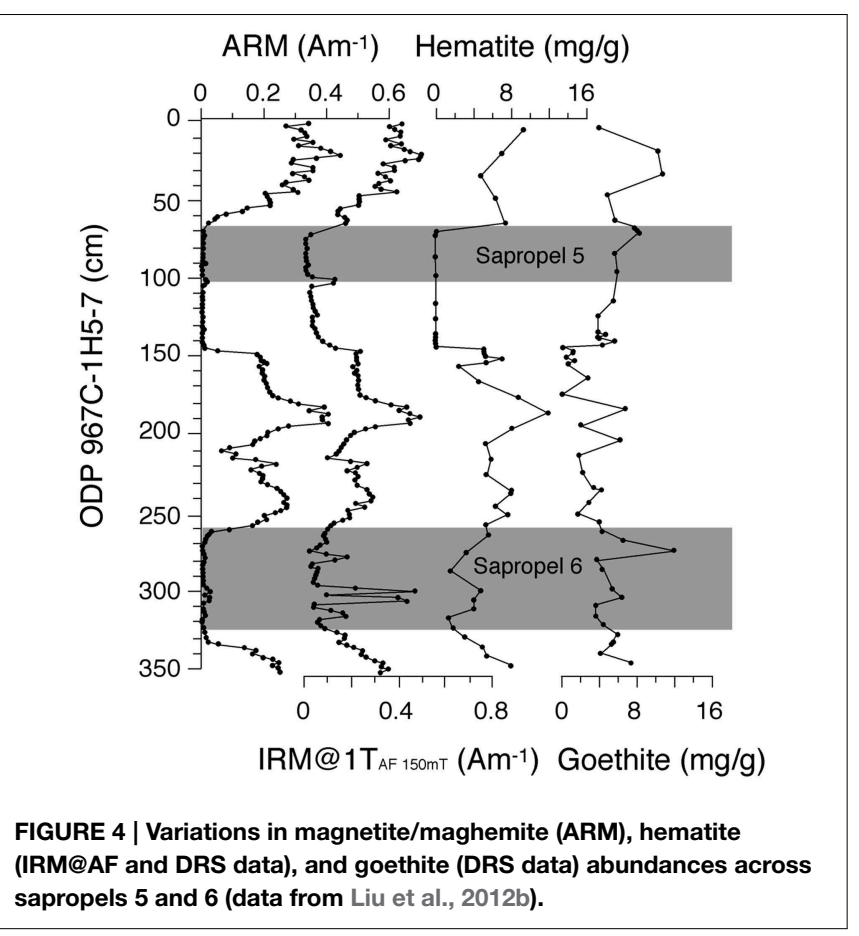

Eastern Mediterranean marine sediments (Balsam et al., 2007). DRS data also indicate that, as opposed to hematite, goethite abundances do not vary systematically between sapropels and background sediments (Liu et al., 2012b) (Figure 4).

Other magnetic minerals reported from Eastern Mediterranean marine sediments include greigite and maghemite. Greigite has been reported within some sapropels with exceptionally high organic carbon contents (Roberts et al., 1999; Larrasoaña et al., 2003b, 2006), which are typically found around eccentricity maxima. Maghemite has been reported in some studies, with the degree of maghemitization appearing to be larger within and immediately below sapropels, lowest above sapropels, and intermediate in background sediments (Passier et al., 2001; Passier and Dekkers, 2002). Partially maghemitized magnetite is, therefore, the dominant magnetic mineral in sediments studied by Passier and Dekkers (2002), with the exception of positions immediately above sapropels (Figure 5).

\section{Discussion}

\section{Origin of Magnetic Minerals in Eastern Mediterranean Marine Sediments Hematite}

HIRM values for NES sediments have a statistically significant monotonically increasing relationship with present-day rainfall (Figure 2B). Despite the large data scatter, we consider that the statistically significant correlation reflects a causal relationship between rainfall and HIRM that is partly blurred by the strikingly variable lithological background, geomorphological setting and weathering stage of the studied samples, which come from a vast study area of $>10^{6} \mathrm{~km}^{2}$ (Lyons et al., 2010). We, therefore, favor the interpretation that most hematite in NES surface

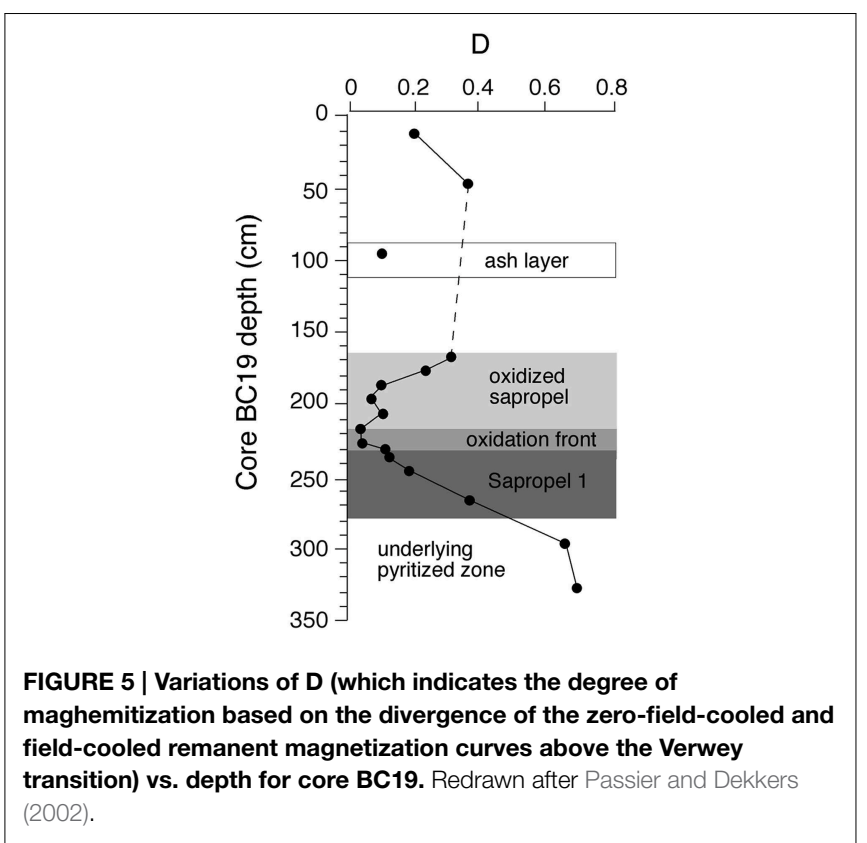

sediments is pedogenic in origin (Lyons et al., 2010, 2012). A comparison of HIRM with ARM data for surface sediments indicates that there is a direct positive correlation between the concentrations of hematite and ferrimagnets. Based on these data, Lyons et al. (2010) suggested that pedogenic hematite formed via the ferrihydrite-maghemite-hematite transformation pathway (Lyons et al., 2010, 2012). In this case, hematite is expected to include SP and SD grains (Liu et al., 2008) that range between 0.05 and $\sim 15 \mu \mathrm{m}$ in size (Evans and Heller, 2003). In addition to this pedogenic component, smaller amounts of lithogenic hematite released during weathering (from the wide variety of hematite-bearing NES rocks) are also expected to occur in surface sediments with a wide range of grain sizes. Surface sediment particles smaller than $\sim 100 \mu \mathrm{m}$ are preferentially entrained by wind as constituents of local dust (Pye, 1989; Maher et al., 2010). Given that the modal size of local NES dust is about 90-100 $\mu \mathrm{m}$ (Smalley et al., 2005; O'Hara et al., 2006), it is not surprising that this dust is enriched in (finer) pedogenic and lithogenic hematite grains with respect to parent surface sediments (Lyons et al., 2012; Oldfield et al., 2014). Grain sizes smaller than $\sim 70 \mu \mathrm{m}$ will eventually be entrained by wind as regional dust that can be subjected to long-distance transportation (Lawrence and Neff, 2009; Maher et al., 2010). Although no magnetic property data are available for NES regional dust, it is likely to be further enriched in hematite grains due to winnowing of coarser $(>70 \mu \mathrm{m})$ particles. As dust travels from the NES toward the Eastern Mediterranean Sea, it is progressively depleted in the coarser fraction to eventually reach the central Eastern Mediterranean Sea, Israel and Crete enriched in the silt and clay fraction (modal sizes of 20-40 $\mu \mathrm{m}$, Yaalon and Ganor, 1979; Mattsson and Nihlén, 1996; Hamann et al., 2008). This fraction is large enough to include both pedogenic and lithogenic hematite grains, which can then reach the Eastern Mediterranean Sea as constituents of eolian dust. This 
is in agreement with the eolian origin that has been proposed for hematite in Eastern Mediterranean marine sediments by comparing HIRM data with proxies for Saharan dust supply, such as Ti/Al ratios (Larrasoaña et al., 2003a, 2008; Köhler et al., 2008; Liu et al., 2012b) (Figure 3).

\section{Magnetite/Maghemite}

Magnetite is ubiquitous in NES rocks with different origins (e.g., marine and continental sedimentary, metamorphic, intrusive, and plutonic rocks), and is, therefore, expected to have a wide range of grain sizes from SP to MD. Release of this magnetite during weathering provides the source for lithogenic magnetite in surface sediments (e.g., distal alluvial, lacustrine, eolian sediments and soils) throughout the NES (Lyons et al., 2010, 2012; Oldfield et al., 2014). These surface sediments also include finer (around the SP/SD threshold size) ferrimagnetic grains; their constant grain size and their increasing concentration with increased rainfall (Figure 2A), regardless of background lithology/geomorphology and weathering stage, also point to a pedogenic origin (Lyons et al., 2010, 2012). These ferrimagnets likely correspond to oxidized magnetite grains or to maghemite grains that formed as an intermediate phase during the ferrihydrite-maghemite-hematite pedogenic transformation pathway (Lyons et al., 2010), which implies a substantial maghemite composition. Such a model has been suggested for most pedogenic environments (Torrent et al., 2006; Liu et al., 2012a), and is likely responsible for the magnetic enhancement observed in soils from the arid and semi-arid tropical belt (Balsam et al., 2011). This pedogenic pathway is supported by some paleomagnetic studies in northern Sudan and the Red Sea coast that reported maghemite and hematite formation (Bachtadse and Briden, 1991; Lean et al., 1998), but not magnetite formation, under present-day hyper-arid weathering conditions (Lean et al., 1998). Further support for this pedogenic pathway comes from the suggestion that magnetite in Eastern Mediterranean marine sediments appears to be invariably maghemitized to some extent, with the exception of paleooxidation fronts that developed above sapropels where relatively fresher biogenic magnetite formed (Passier and Dekkers, 2002) (Figure 5). In this case, it is also likely that airborne lithogenic magnetite grains would have undergone oxidation and maghemitization on their outer surfaces. In the following, we refer to these ferrimagnetic grains as magnetite/maghemite.

Local dust samples contain a fine (SP/SD) pedogenic magnetite/maghemite fraction along with a coarser lithogenic (likely also maghemitized) magnetite component, where the concentration of the former is significantly larger than in nearby surface sediments (Lyons et al., 2012; Oldfield et al., 2014). This indicates that surface sediments are depleted in SP/SD magnetite/maghemite grains, which dominate the finer grain-size fraction and are, therefore, preferentially entrained by wind in local dust plumes (Oldfield et al., 2014). PSD and MD magnetite grains fall in the $2-15 \mu \mathrm{m}$ and $>15 \mu \mathrm{m}$ grain sizes, respectively (Dunlop, 2002), which is significantly smaller than the modal size of both local dust (90-100 $\mu \mathrm{m}$, Smalley et al., 2005; O'Hara et al., 2006) and regional dust arriving to the Eastern Mediterranean Sea (20-40 $\mu \mathrm{m}$; Yaalon and Ganor, 1979; Mattsson and Nihlén,
1996; Hamann et al., 2008). It is, therefore, expected that both fine-grained pedogenic magnetite/maghemite and relatively coarser lithogenic (possibly maghemitized) magnetite grains will accumulate in Eastern Mediterranean marine sediments as constituents of eolian dust, as has been also reported for eolian sediments on the Chinese Loess Plateau (Liu et al., 2007a). The eolian origin of magnetite/maghemite is further demonstrated on the basis of comparisons between ARM and geochemical and mineralogical data from different terrigenous sources, including eolian dust (Kruiver and Passier, 2001; Passier et al., 2001; Larrasoaña et al., 2008). For example, the midPleistocene transition at about $0.95 \mathrm{Ma}$ witnessed a sharp increase in eolian dust concentration as recorded by both hematite and magnetite/maghemite abundances (Figure 3). ARM values for Eastern Mediterranean marine sediments, NES surface sediments, and NES local and regional dusts are systematically smaller than HIRM or IRM@AF values for the same sediments. Given that the saturation magnetization of hematite $(\sim 0.4$ $\mathrm{Am}^{2} \mathrm{~kg}^{-1}$; Tauxe, 2010) is much smaller than that of magnetite or maghemite (74-92 $\mathrm{Am}^{2} \mathrm{~kg}^{-1}$, Tauxe, 2010), the concentrations of hematite must be a few hundred times larger than those of magnetite/maghemite throughout the dust pathway from its source in the NES to its sink in deep Eastern Mediterranean basins. The average HIRM to ARM ratio decreases from around 10 for NES surface sediments to around 2-4 for local and regional NES dust samples and Eastern Mediterranean marine sediments. This suggests preferential eolian entrainment of pedogenic magnetite/maghemite with respect to pedogenic hematite. A possible explanation is that pedogenic hematite often coats quartz grains that are too large to be entrained by wind (El-Baz, 1986). The average IRM@AF to ARM ratio for background Eastern Mediterranean marine sediments is about 2, which is similar to that reported for local and regional NES dust samples. Although the apparatus and experimental settings used to impart these laboratory-induced magnetic properties were slightly different, it nevertheless indicates that, once in the air, the relative abundances of magnetite/maghemite and hematite remain constant. This indicates that dissolution and reprecipitation reactions during transportation have a minor effect on the magnetic mineral assemblage (Maher, 2011), probably in response to the rapid journey (10-20 days, Lee et al., 2009) taken by dust particles from their source in the NES to their sink in deep Eastern Mediterranean basins, or that their effect is restricted to the finest pedogenic hematite and magnetite/maghemite grains (which do not contribute to IRM@AF and ARM, respectively).

\section{Goethite}

Goethite is present in a relatively low number of NES rock units (Davies et al., 1980; Bachtadse and Briden, 1991; Abdeldayem, 1996, 1999; Lotfy and van der Voo, 2007; Lotfy, 2011), and has been reported to occur in some regions under present-day weathering conditions (Lean et al., 1998; Abdeldayem, 1999). The relatively minor abundance of goethite reported in Eastern Mediterranean marine sediments by Balsam et al. (2007) seems to support its eolian origin, bearing in mind its less frequent occurrence also in NES source rocks and dust (Lyons et al., 2010, 2012). However, goethite abundances do not undergo systematic 
variations across sapropels (Liu et al., 2012b) as opposed to hematite (Figure 4) or other proxies for eolian dust, so that a uniquely eolian origin cannot be demonstrated unambiguously.

\section{Magnetic Iron Sulfides}

Although magnetic iron sulfides might be present in some NES source rocks, they are expected to oxidize during weathering and transportation (Horng and Roberts, 2006; Liu et al., 2012a). The lack of greigite or pyrrhotite in NES surface sediments and dust (Lyons et al., 2010, 2012) indicates that this is the case, and that post-depositional processes must control the occasional occurrence of greigite in sediments in deep Eastern Mediterranean basins (Roberts et al., 1999).

\section{Diagenetic Imprint on Magnetic Minerals}

Magnetite/maghemite appears to be severely affected by diagenetic processes in the vicinity of sapropels. Thus, high organic carbon contents and prevailing sulphidic conditions during sapropel formation are responsible for the pervasive reductive dissolution of fine-grained magnetite/maghemite within and below sapropels, which explains the lowest ARM values observed at these positions (Figure 3) (Van Santvoort et al., 1997; Kruiver and Passier, 2001; Larrasoaña et al., 2003a, 2006, 2008; Liu et al., 2012b). Above sapropels, high ARM values have been interpreted to result from authigenic magnetite growth, mostly biogenic, at paleo-oxidation fronts that developed above sapropels when oxic conditions were reestablished after their formation (Figure 3) (Kruiver and Passier, 2001; Passier et al., 2001; Liu et al., 2012b). In contrast to magnetite/maghemite, the striking correlation between hematite abundances and $\mathrm{Ti} / \mathrm{Al}$ values, even in the vicinity of sapropels (Figure 3), indicates that hematite is largely unaffected by short-term periods of sulphidic diagenesis associated with accumulation and degradation of organic matter in sapropels. Exceptions occur in some strongly sulphidic sapropels that tend to cluster around prominent eccentricity maxima (black arrows in Figure 3). Lowest ARM and IRM@AF values across these sapropels and throughout intermediate background sediments indicate reductive dissolution of even the more resistant hematite grains (Larrasoaña et al., 2003b). Goethite is even less affected by reductive dissolution within and below sapropels, even in strongly sulphidic sapropels (Liu et al., 2012b). These results contrast with the reactivity of iron-bearing minerals to sulfide, where magnetite has a similar reactivity to goethite and hematite (Poulton et al., 2004). It also contrasts with other studies in which goethite has been reported to be more sensitive to reductive dissolution than hematite (Abrajevitch and Kodama, 2011). This discrepancy can be explained by the grain size of different magnetic minerals in Eastern Mediterranean marine sediments. Pedogenic SP/SD magnetite/maghemite grains range typically between 0.01 and $0.1 \mu \mathrm{m}$, and coarser lithogenic grains are typically $>1 \mu \mathrm{m}$ (Maher, 2011). In contrast, pedogenic hematite grains can range between 0.05 and $15 \mu \mathrm{m}$ in size (Evans and Heller, 2003; Maher, 2011), and lithogenic hematite grains can be even larger (Evans and Heller, 2003; Maher, 2011). Dissolution depends largely on the surface area to volume ratio, therefore the smaller grain sizes of magnetite/maghemite particles compared to those of hematite can explain their preferential dissolution within and below sapropels. A similar situation is expected for goethite, which is even more resistant to dissolution than hematite. Greigite has been reported within some sapropels with exceptionally high organic carbon contents. While this has been taken as an indication of a diagenetic origin (Roberts et al., 1999; Larrasoaña et al., 2003b), recent results from Baltic Sea sapropels (Reinholdsson et al., 2013) suggest that greigite in these sapropels might have a biogenic origin.

\section{Influence of Past Wetter Periods}

Present-day hyper-arid conditions in the NES severely limit pedogenic processes, which limits production of pedogenic magnetite/maghemite and hematite (Figure 2). These conditions contrast sharply with those that prevailed during past GSPs. In order to assess the role of these periods on the type and production of pedogenic magnetic minerals, it is necessary to recall: (1) the overall environmental conditions during GSPs; (2) the relationship between pedogenic hematite and magnetite/maghemite abundances with respect to presentday precipitation variations (Figure 2) (Lyons et al., 2010, 2012); and (3) paleoprecipitation estimates for representative GSPs. Paleoenvironmental reconstructions indicate mean annual precipitation of around 100-300 and 400-600 mm/year throughout the core of the NES during the Holocene (Kuper and Kröpelin, 2006; Larrasoaña et al., 2013) and Eemian GSPs (Kowalski et al., 1989; Kieniewicz and Smith, 2009; Larrasoaña et al., 2013), respectively. These conditions, coupled with overall warmer temperatures and the seasonal nature of monsoonal Saharan precipitation, suggest that pedogenic magnetite/maghemite and hematite production was favored compared to goethite production during most GSPs (Schwertmann and Taylor, 1989; Balsam et al., 2011; Maher, 2011; Quinton et al., 2011). Conditions significantly wetter than those during the Eemian GSP appear to have occurred during older GSPs (Geyh and Thiedig, 2008), especially before $1 \mathrm{Ma}$ (Drake et al., 2008; Larrasoaña et al., 2013). This suggests that some pedogenic goethite might have also formed during these wetter GSPs (Balsam et al., 2011). Goethite is metastable under dry and warm conditions, and will eventually dehydrate to hematite. This process is completed below $325^{\circ} \mathrm{C}$ under laboratory conditions, but might proceed at lower temperatures given enough time (Tauxe, 2010). Surface air temperatures in the NES often exceed $50^{\circ} \mathrm{C}$ and soil temperatures might reach $\sim 80^{\circ} \mathrm{C}$ (Laity, 2008). We infer that dehydration under dominant desert conditions of any pedogenic goethite that formed during past wetter GSPs is responsible for the scarcity of goethite reported for rocks, surface sediments and local dust from the NES.

The statistically-significant regressions established between ARM and HIRM with present-day precipitation variations indicate that Holocene and Eemian GSP conditions would have given rise to a remarkable (e.g., 2-4 fold) increase in production of pedogenic magnetite/maghemite (Figure 2A), and an even higher (e.g., 4-6 fold) increase in the production of pedogenic hematite (Figure 2B), with respect to background hyper-arid conditions. Although these values are rough 
estimates based on the limited data available for present-day conditions, they nevertheless stress the importance of GSPs in production of magnetite/maghemite and hematite grains that are later transported into the Eastern Mediterranean Sea as constituents of NES dust. This is especially the case for hematite, which has concentrations a few hundred times larger than magnetite/ maghemite throughout the dust pathway. This apparent excess of pedogenic hematite production with respect to magnetite/maghemite during GSPs appears to be irrelevant at eccentricity maxima, where recurrent GSPs enabled formation of pedogenic magnetic minerals in sufficient amounts to sustain their entrainment by wind throughout the following desert phase. It was important, however, at eccentricity minima during which only minor amounts of pedogenic hematite and magnetite/maghemite could form under prolonged hyper-arid desert conditions. Thus, large amounts of pedogenic hematite that formed during previous GSPs appear to explain the overall higher abundances of hematite documented throughout long (e.g., 200 kyr) sapropel-barren Eastern Mediterranean marine sequences, as opposed to the roughly constant magnetite/maghemite concentrations throughout the same intervals (e.g., Larrasoaña et al., 2003a). Dehydration of any pedogenic goethite that formed during earlier GSPs might provide an additional source of hematite during deposition of sapropel-barren sequences under prevailing desert conditions. Overall, these data suggest that the NES dust system is not supply-limited with regard to hematite, but it seems to be so in the case of magnetite/maghemite.

Past GSPs likely altered not only the amount of pedogenically produced magnetic minerals, but also their properties. For example, enhanced pedogenesis may have favored initial substitution of iron by aluminum in hematite, which will increase its coercivity (Maher, 2011; Liu et al., 2012a). Such a coercivity increase in pedogenic hematite during GSPs might explain the strong correlation between coercivity and HIRM values reported by Liu et al. (2007b) within sapropels. Such a correlation was not found for background sediments, which indicates that the coercivity of eolian hematite in background Eastern Mediterranean marine sediments is relatively invariant (Liu et al., 2007b). However, this clearly contrasts with the coercivity increase of hematite reported by Lyons et al. $(2010,2012)$ as a function of latitude (and hence rainfall) for NES surface sediments and local dust. The most plausible explanation for this discrepancy is that pedogenic hematite with different coercivities throughout the NES is effectively mixed during entrainment and transportation by wind into the Eastern Mediterranean Sea, which results in a more homogeneous final coercivity distribution.

\section{Paleoenvironmental Significance of Magnetic Records from Eastern Mediterranean Marine Sediments}

Hematite in Eastern Mediterranean deep-sea sediments has been interpreted to be mainly of eolian origin (Larrasoaña et al., 2003a, 2008; Köhler et al., 2008; Liu et al., 2012b), with diagenetic changes in its abundance occurring only below extremely organic-rich sapropels (Larrasoaña et al., 2003b, 2006, 2008). These studies have also proposed a dominantly eolian origin for magnetite in background sediments (Kruiver and Passier, 2001; Passier et al., 2001; Larrasoaña et al., 2008), with a minor contribution from other terrigenous (e.g., fluvial and volcanic) or biogenic sources at some stratigraphic intervals (Dinarès-Turell et al., 2003; Larrasoaña et al., 2008; Roberts et al., 2012). An eolian origin has also been proposed for goethite (Heslop et al., 2007; Köhler et al., 2008; Liu et al., 2012b), and a diagenetic (Roberts et al., 1999; Larrasoaña et al., 2003b, 2006) or biogenic origin (Roberts, 2015, submitted) has been proposed for greigite.

The source-to-sink approach adopted here validates most of these previous interpretations, but, more importantly, it provides new insights that are summarized in Figure 6. Concerning hematite, our approach indicates that both lithogenic grains released during weathering from NES rocks, along with a dominant pedogenic component, accumulate in deep Eastern Mediterranean basins as constituents of regional dust that emanated from the NES (e.g., PSA4 of Scheuvens et al., 2013). Most eolian hematite appears to have formed during short, but significantly wetter than present GSPs that promoted increased pedogenic activity throughout the NES. Such conditions appear to have resulted in production of pedogenic hematite in amounts large enough to keep pace with increased entrainment of eolian dust during hyper-arid desert phases, even when they prevailed throughout long (e.g., several hundreds of thousands of years) periods of time. The lack of a significant influence of coercivity variations on hematite abundances in background Eastern Mediterranean marine sediments suggests that pedogenic hematite throughout the source area is effectively mixed during eolian entrainment and transportation into deep Eastern Mediterranean basins. These conditions, along with the limited impact of reductive dissolution (linked to relatively large grain sizes), indicate that hematite abundances (inferred from HIRM or IRM@AF data) provide reliable quantitative estimates of NES eolian dust supply into the Eastern Mediterranean Sea. A next relevant issue is to unravel the paleoclimatic significance of such variations. Our data demonstrate that eolian hematite deposition was minimal during GSPs (e.g., sapropels) despite the fact that it was precisely at those times when pedogenic hematite mainly formed throughout the NES and when the mechanism that brings eolian dust to the Eastern Mediterranean Sea (e.g., the passage of mid-latitude depressions) likely was intensified (Zhao et al., 2012; Larrasoaña et al., 2013). We, therefore, interpret lowest eolian dust fluxes into the Eastern Mediterranean Sea during GSPs to have resulted from widespread expansion of savannah vegetation throughout the NES, which then blocked entrainment of eolian dust regardless of prevailing favorable atmospheric conditions for its transportation. After cessation of each GSP, concomitant southerly retreat of savannah vegetation enabled activation of eolian dust entrainment and its transportation from the NES. These data indicate that Eastern Mediterranean marine records of dust deposition reflect an on-off mechanism in which a key control on eolian inputs is provided by the presence of vegetation cover in the source area, which is intimately associated 

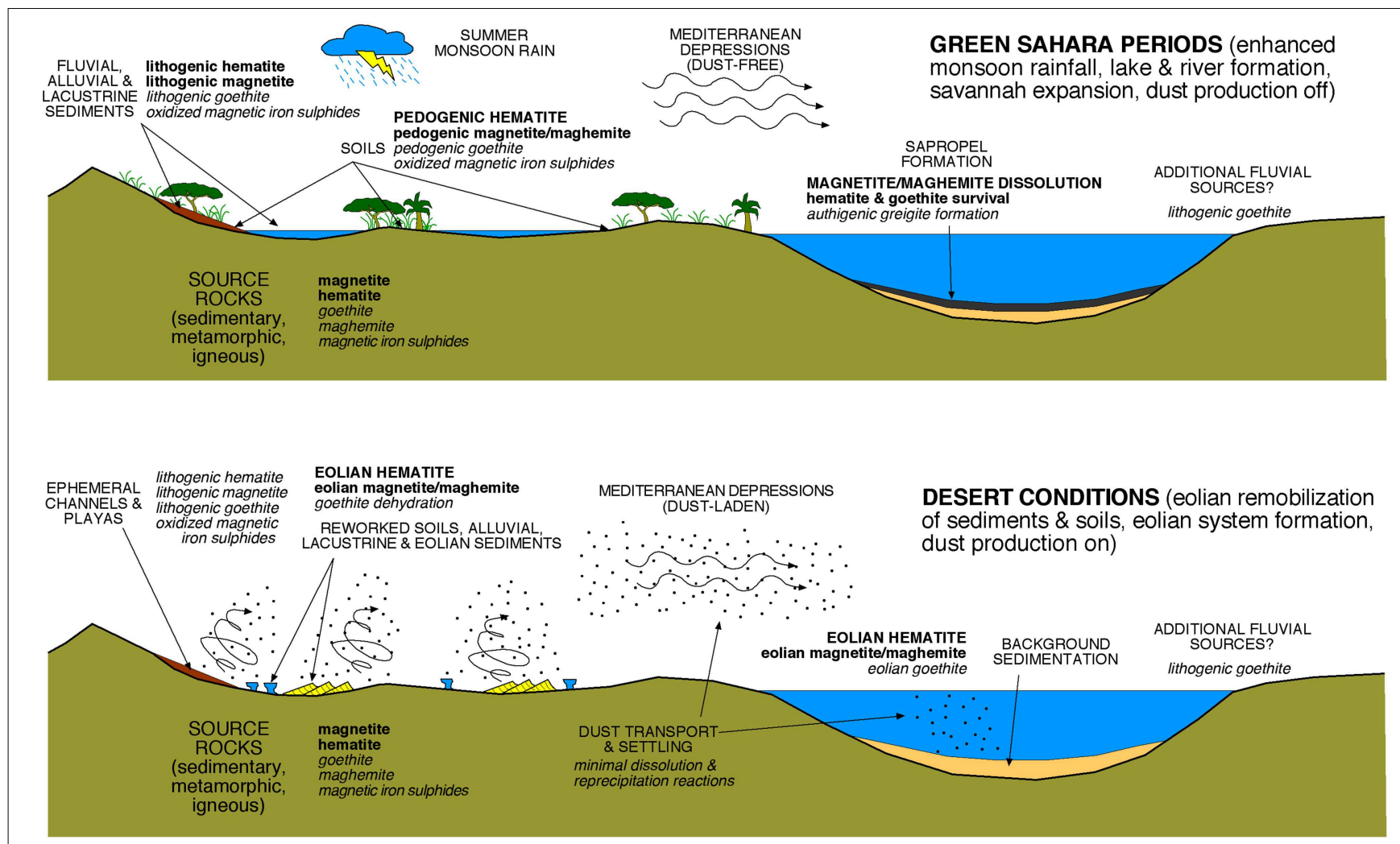

FIGURE 6 | Schematic illustration of source-to-sink pathway for magnetic minerals during present-day conditions (lower panel) and Green Sahara Periods (upper panel). Different processes and magnetic minerals are labeled as dominant (capitalized, bold, and italics), frequent (bold and italics), and occasional (italics). with wetter conditions driven by enhanced monsoon dynamics (Larrasoaña et al., 2013).

For magnetite, available data indicate that lithogenic grains and a dominant pedogenic component reach deep Eastern Mediterranean basins as constituents of NES regional dust. Eolian magnetite appears to be invariably affected by some degree of maghemitization due to its dominantly pedogenic origin. Once buried in sediments, accumulation and degradation of organic matter drives short-lived periods of reductive dissolution of magnetite/maghemite grains within and below sapropels, and authigenic magnetite growth at the top of sapropels. Such diagenetic reactions obscure signals associated with eolian magnetite/maghemite abundances in stratigraphic intervals with frequent sapropel occurrences. Pedogenic magnetite/maghemite production in the NES also appears to have increased during GSPs, but not in amounts that were able to keep pace with eolian dust entrainment as was the case with hematite. This indicates that magnetic parameters used to disentangle magnetite/maghemite abundance (e.g., ARM) are unlikely to provide reliable quantitative estimates of eolian dust deposition even through long (e.g., several hundreds of thousands of years) sapropel-barren intervals where the diagenetic impact on eolian magnetite/maghemite abundances is minimal. With these caveats in mind, it seems that the main application of ARM data in Eastern Mediterranean Sea sediments is to delineate long-term changes in diagenetic conditions, which are mainly driven by the interplay between organic matter content within sapropels and bottom water ventilation (Larrasoaña et al., 2003b, 2006).

Goethite has been identified in a relatively small number of NES rocks, surface sediments and local dust samples, probably because it is metastable under hyper-arid and warm presentday conditions. This, along with a lack of systematic variation in goethite abundance across sapropels, suggests that other processes besides eolian dust supply control goethite occurrences in Eastern Mediterranean marine sediments. Authigenic growth of goethite is unlikely given its occurrence in sapropels that formed under anoxic conditions. A likely possibility is that goethite is delivered into the Eastern Mediterranean Sea by fluvial inputs from its northern borderlands, where cooler and wetter conditions would favor pedogenic goethite formation (Maher, 2011; Quinton et al., 2011). The River Nile is another potential source of detrital goethite derived from the wetter tropical regions of its headwaters. Regardless of its origin, it is unlikely that goethite abundance records in Eastern Mediterranean marine sediments can be produced due to its high coercivity, which renders it "invisible" in most magnetic measurements. Likewise, identification of greigite is unlikely to provide widely useful information concerning depositional conditions given that its occurrence is restricted largely to sapropels with exceptionally high organic carbon contents. 


\section{Conclusions}

The source-to-sink approach adopted in this study has provided novel insights into the occurrence and origin of magnetic minerals in NE Saharan dust, the climatic conditions under which they originated, and their paleoenvironmental significance once preserved in Eastern Mediterranean marine sediments. Hematite is the most abundant magnetic mineral in NES dust, and mainly formed pedogenically during short, but significantly wetter than present periods (GSPs), that promoted increased pedogenic activity throughout the NES. Coupled with the limited impact of reductive diagenesis on hematite abundances, variations in hematite concentration in Eastern Mediterranean marine sediments provide reliable quantitative estimates of eolian dust supply from the neighboring NES. Eastern Mediterranean marine records of NES dust deposition based on hematite abundances record an on-off mechanism in which a key control on eolian inputs is provided by vegetation cover in the source area during GSPs, which is intimately associated with wetter conditions driven by enhanced monsoon precipitation. Magnetite/maghemite is also a common magnetic mineral in NE Saharan dust, and also formed pedogenically during GSPs but in much smaller amounts compared to hematite. Limited pedogenic production of magnetite/maghemite in the source area during GSPs, along with the later imprint of diagenesis, indicates that magnetite/maghemite abundances cannot be used to estimate dust inputs quantitatively from the NES into the Eastern Mediterranean Sea. Goethite cannot be

\section{References}

Abdeldayem, A. L. (1996). Palaeomagnetism of some Miocene rocks, Qattara depression, Western Desert, Egypt. J. Afr. Earth Sci. 22, 525-533. doi: 10.1016/0899-5362(96)00034-6

Abdeldayem, A. L. (1999). Palaeomagnetism of some Cenozoic sediments, CairoFayum area, Egypt. Phys. Earth Planet. Inter. 110, 71-82. doi: 10.1016/S00319201(98)00139-3

Abrajevitch, A., and Kodama, K. (2011). Diagenetic sensitivity of paleoenvironmental proxies: a rock magnetic study of Australian continental margin sediments. Geochem. Geophys. Geosyst. 12:Q05Z24. doi: 10.1029/2010GC003481

Bachtadse, V., and Briden, J. C. (1991). Paleomagnetism of Devonian ring complexes from the Bayuda Desert, Sudan - new constraints on the apparent polar wander path for Gondwanaland. Geophys. J. Int. 104, 635-646. doi: 10.1111/j.1365-246X.1991.tb05707.x

Bailey, I., Liu, Q. S., Swann, G. E. A., Jiang, Z. X., Sun, Y. B., Zhao, X., et al. (2011). Iron fertilisation and biogeochemical cycles in the sub-Arctic northwest Pacific during the late Pliocene intensification of northern hemisphere glaciation. Earth Planet. Sci. Lett. 307, 253-265. doi: 10.1016/j.epsl.2011.05.029

Balsam, W., Arimoto, R., Ji, J., Shen, Z., and Chen, J. (2007). Aeolian dust in sediment: a re-examination of methods for identification and dispersal assessed by diffuse reflectance spectrophotometry. Int. J. Environ. Health 1, 374-402. doi: 10.1504/IJENVH.2007.017868

Balsam, W. L., Ellwood, B. B., Ji, J., Williams, E. R., Long, X., and El Hassani, A. (2011). Magnetic susceptibility as a proxy for rainfall: worldwide data from tropical and temperate climate. Quat. Sci. Rev. 30, 2732-2744. doi: 10.1016/j.quascirev.2011.06.002

Besler, H. (2000). Modern and palaeo-modelling in the Great Sand Sea of Egypt (initial results from the Cologne Cooperative Research Project 389). Global Planet. Change 26, 13-24. doi: 10.1016/S0921-8181(00)00031-X used either to estimate variations in NES dust supply because its occurrence in Eastern Mediterranean marine sediments appears to be linked to fluvial inputs in addition to eolian activity.

In the last decade, adoption of a source-to-sink approach to environmental magnetic studies of sedimentary sequences in marine (e.g., Horng and Roberts, 2006; Horng and Huh, 2011) and continental (e.g., Dearing et al., 2001; Lanci et al., 2008) environments, including eolian systems (Maher, 2011), has provided novel insights on the paleoenvironmental significance of sediment magnetic properties. Our data reinforce the view that source-to-sink environmental magnetic studies should be conducted routinely to better understand the complex combined processes involved in producing, transporting, depositing and diagenetically modifying magnetic minerals in sedimentary environments (Liu et al., 2012a).

\section{Author Contributions}

JL designed the study and led the discussion of results and writing of the paper with input from all co-authors.

\section{Acknowledgments}

AR and DH gratefully acknowledge support from Australian Research Council grant DP110105419, and ER acknowledges support from 2012 Australia Laureate Fellowship FL120100050.

Bloemendal, J., and deMenocal, P. B. (1989). Evidence for a change in the periodicity of tropical climate cycles at $2.4 \mathrm{Myr}$ from whole-core magnetic susceptibility measurements. Nature $342,887-890$. doi: 10.1038/342897a0

Bloemendal, J., King, J. W., Hunt, A., deMenocal, P. B., and Hayashida, A. (1993). Origin of the sedimentary magnetic record at the Ocean Drilling Program sites on the Owen Ridge. J. Geophys. Res. 98, 4199-4219. doi: 10.1029/92JB 02914

Bory, A. J. M., Biscaye, P. E., and Grousset, F. E. (2003). Two distinct seasonal Asian source regions for mineral dust deposited in Greenland (NorthGRIP). Geophys. Res. Lett. 30:1167. doi: 10.1029/2002GL016446

Chester, R., Sharples, E. J., Sanders, G., Oldfield, F., and Saydam, A. C. (1984) The distribution of natural and non-crustal ferrimagnetic minerals in soil-sized particulates from the Mediterranean atmosphere. Water Air Soil Pollut. 85, 25-35. doi: 10.1007/BF00185128

Conover, W. J., and Iman, R. L. (1981). Rank transformations as a bridge between parametric and nonparametric statistics. Am. Stat. 35, 124-119. doi: $10.2307 / 2683975$

Crouvi, O., Schepanski, K., Amit, R., Gillespie, A. R., and Enzel, Y. (2012). Multiple dust sources in the Sahara Desert: the importance of sand dunes. Geophys. Res. Lett. 39:L13401. doi: 10.1029/2012GL052145

Davies, J., Nairm, A. E. M., and Ressetar, R. (1980). The paleomagnetism of certain late Precambrian and early Paleozoic rocks from the Red Sea hills, Eastern Desert, Egypt. J. Geophys. Res. 85, 3699-3710. doi: 10.1029/JB085iB07p03699

Dearing, J., Hu, Y. Q., Doody, P., James, A. P., and Brauer, A. (2001). Preliminary reconstruction of sediment-source linkages for the past $6000 \mathrm{yr}$ at the Petit Lac d'Annecy, France, based on mineral magnetic data. J. Paleolimnol. 25, 245-258. doi: 10.1023/A:1008186501993

deMenocal, P., Bloemendal, J., and King, J. (1991). A rock-magnetic record of monsoonal dust deposition to the Arabian Sea: evidence for a shift in the mode of deposition at $2.4 \mathrm{Ma}$. Proc. ODP Sci. Res. 177, 389-407. doi: 10.2973/odp.proc.sr.117.178.1991 
deMenocal, P. B. (1995). Plio-Pleistocene African climate. Science 270, 53-59. doi: 10.1126/science.270.5233.53

Dinarès-Turell, J., Hoogakker, B. A. A., Roberts, A. P., Rohling, E. J., and Sagnotti, L. (2003). Quaternary climatic control of biogenic magnetite production and eolian dust input in cores from the Mediterranean Sea. Palaeogeogr. Palaeoclimatol. Palaeoecol. 64, 221-240. doi: 10.1016/S0031-0182(02)00605-3

Ding, Z. L., Ranov, V., Yang, S. L., Finaev, A., Han, J. M., and Wang, G. A. (2002). The loess record in southern Tajikistan and correlation with Chinese loess. Earth Planet. Sci. Lett. 200, 387-400. doi: 10.1016/S0012-821X(02)00637-4

Doh, S. J., King, J., and Leinen, M. (1988). A rock-magnetic study of giant piston core LL44-GPC3 from the central North Pacific and its paleoceanographic implications. Paleoceanography 3, 89-111. doi: 10.1029/PA003i001p00089

Drake, N. A., Blench, R. M., Armitage, S. J., Bristow, C. S., and White, K. H. (2011). Ancient watercourses and biogeography of the Sahara explain the peopling of the desert. Proc. Natl. Acad. Sci. U.S.A. 108, 458-462. doi: 10.1073/pnas. 1012231108

Drake, N. A., El-Hawat, A. S., Turner, P., Armitage, S. J., Salem, M. J., White, K. H., et al. (2008). Palaeohydrology of the Fazzan Basin and surrounding regions: the last 7 million years. Palaeogeogr. Palaeoclimatol. Palaeoecol. 263, 131-145. doi: 10.1016/j.palaeo.2008.02.005

Dunlop, D. J. (2002). Theory and application of the Day plot $\left(M_{r s} / M_{s}\right.$ versus $\left.H_{c r} / H_{c}\right)$ 2. Application to data for rocks, sediments and soils. J. Geophys. Res. 107, B3. doi: 10.1029/2001JB000487

El-Baz, F. (1986). "On the reddening of quartz grains in dune sand," in Physics of Desertification, eds F. El-Baz and M. H. A. Hassan (Dordrecht: Martinus Nijhoff), 191-209.

Emeis, K. C., Sakamoto, T., Wehausen, R., and Brumsack, H. J. (2000). The sapropel record of the eastern Mediterranean Sea - results of Ocean Drilling Program Leg 160. Palaeogeogr. Palaeoclimatol. Palaeoecol. 158, 371-395. doi: 10.1016/S0031-0182(00)00059-6

Engelstaedter, S., Tegen, I., and Washington, R. (2006). North African dust emissions and transport. Earth Sci. Rev. 79, 73-100. doi: 10.1016/j.earscirev.2006.06.004

Evans, M. E., and Heller, F. (2003). Environmental Magnetism: Principles and Applications of Enviromagnetics. San Diego, CA: Academic Press.

Field, J. P., Belnap, J., Breshears, D. D., Neff, J. C., Okin, G. S., Whicker, J. J., et al. (2010). The ecology of dust. Front. Ecol. Environ. 8, 423-430. doi: $10.1890 / 090050$

Food and Agriculture Organization of the United Nations (FAO), International Institute for Applied Systems Analysis, International Soil Reference and Information Centre, Institute of Soil Science - Chinese Scdemy of Sciences, and Joint Research Centre of the European Comission. (2009). Harmonized World Soil Database (Version 1.1). Available online at: http://www.isric.org/content/ harmonized-world-soil-database-version-12 (FAO, Rome).

Gasse, F. (2000). Hydrological changes in the African tropics since the Last Glacial Maximum. Quat. Sci. Rev. 19, 189-211. doi: 10.1016/S0277-3791(99)00061-X

Geyh, M. A., and Thiedig, F. (2008). The Middle Pleistocene Al Mahrúqah Formation in the Murzuq Basin, northern Sahara, Libya: evidence for orbitally-forced humid episodes during the last 500,000 years. Palaeogeogr. Palaeoclimatol. Palaeoecol. 257, 1-21. doi: 10.1016/j.palaeo.2007.07.001

Goudie, A. S., and Middleton, N. J. (2001). Saharan dust storms: nature and consequences. Earth Sci. Rev. 56, 179-204. doi: 10.1016/S0012-8252(01) 00067-8

Hamann, Y., Ehrmann, W., Schmiedl, G., Krüger, S., Stuut, J. B., and Kuhnt, T. (2008). Sedimentation processes in the Eastern Mediterranean Sea during the Late Glacial and Holocene revealed by end-member modeling of the terrigenous fraction in marine sediments. Mar. Geol. 248, 97-114. doi: 10.1016/j.margeo.2007.10.009

Heslop, D., von Dobeneck, T., and Hoecker, M. (2007). Using non-negative matrix factorization in the "unmixing" of diffuse reflectance spectra. Mar. Geol. 241, 63-78. doi: 10.1016/j.margeo.2007.03.004

Hesse, P. P. (1994). Evidence for bacterial palaeoecological origin of mineral magnetic cycles in oxic and sub-oxic Tasman sea sediments. Mar. Geol. 117, 1-17. doi: 10.1016/0025-3227(94)90003-5

Hilgen, F. J., Krijgsman, W., Langereis, C. G., Lourens, L. J., Santarelli, A., and Zachariasse, W. J. (1995). Extending the astronomical (polarity) time scale into the Miocene. Earth Planet. Sci. Lett. 136, 495-510. doi: 10.1016/0012$821 \mathrm{X}(95) 00207-\mathrm{S}$
Horng, C. S., and Huh, C. A. (2011). Magnetic properties as tracers for source-tosink dispersal of sediments: a case study in the Taiwan Strait. Earth Planet. Sci. Lett. 309, 141-152. doi: 10.1016/j.epsl.2011.07.002

Horng, C. S., and Roberts, A. P. (2006). Authigenic or detrital origin of pyrrhotite in sediments?: Resolving a paleomagnetic conundrum. Earth Planet. Sci. Lett. 241, 750-762. doi: 10.1016/j.epsl.2005.11.008

Hounslow, M. W., and Maher, B. A. (1999). Source of the climate signal recorded by magnetic susceptibility variations in Indian Ocean deep-sea sediments. J. Geophys. Res. 104, 5047-5061. doi: 10.1029/1998JB900085

Hussain, A. G., and Aziz, Y. (1983). Paleomagnetism of Mesozoic and Tertiary rocks from east El-Owenat area, southwest Egypt. J. Geophys. Res. 88, 3523-3529. doi: 10.1029/JB088iB04p03523

Itambi, A. C., von Dobeneck, T., Mulitza, S., Bickert, T., and Heslop, D. (2009). Millennial-scale northwest African droughts related to Heinrich events and Dansgaard-Oeschger cycles: evidence in marine sediments from offshore Senegal. Paleoceanography 24, PA1205. doi: 10.1029/2007PA001570

Junge, C. (1979). "The importance of mineral dust as an atmospheric constituent," in Saharan Dust: Mobilization, Transport, Deposition, ed C. Morales (Chichester: Wiley), 49-60.

Just, J., Heslop, D., von Dobeneck, T., Bickert, T., Dekkers, M., Frederichs, T., et al. (2012). Multiproxy characterization and budgeting of terrigenous endmembers at the NW African continental margin. Geochem. Geophys. Geosyst. 13, Q0AO01. doi: 10.1029/2012GC004148

Kieniewicz, J. M., and Smith, J. R. (2009). Paleoenvironmental reconstruction and water balance of a mid-Pleistocene pluvial lake, Dakhleh Oasis, Egypt. Geol. Soc. Am. Bull. 121, 1154-1171. doi: 10.1130/B26301.1

Köhler, C. M., Heslop, D., Dekkers, M. J., Krijgsman, W., van Hinsbergen, D. J. J., and von Dobeneck, T. (2008). Tracking provenance change during the late Miocene in the eastern Mediterranean using geochemical and environmental magnetic parameters. Geochem. Geophys. Geosyst. 9:Q12018. doi: 10.1029/2008GC002127

Kowalski, K., Bochenski, Z., Mlynarski, M., Rzebik-Kowalska, B., Szyndlar, Z., Gautier, A., et al. (1989). A last interglacial fauna from the eastern Sahara. Quat. Res. 32, 335-341. doi: 10.1016/0033-5894(89)90099-9

Kruiver, P. P., and Passier, H. F. (2001). Coercivity analysis of magnetic phases in sapropel S1 related to variations in redox conditions, including an investigation of the S ratio. Geochem. Geophys. Geosyst. 2, 1063. doi: 10.1029/2001GC000181

Kuper, R., and Kröpelin, S. (2006). Climate-controlled Holocene occupation in the Sahara: motors of Africa's evolution. Science 313, 803-807. doi: $10.1126 /$ science. 1130989

Laity, J. (2008). Deserts and Desert Environments. Chichester: Wiley-Blackwell.

Lanci, L., Delmote, B., Maggi, V., Petit, J. R., and Kent, D. V. (2008). Ice magnetization in the EPICA-Dome $\mathrm{C}$ ice core: implications for dust sources during glacial and interglacial periods. J. Geophys. Res. 113, D14207, doi: 10.1029/2007JD009678

Larrasoaña, J. C., Roberts, A. P., Hayes, A., Wehausen, R., and Rohling, E. J. (2006). Detecting missing beats in the Mediterranean climate rhythm from magnetic identification of oxidized sapropels (Ocean Drilling Program Leg 160). Phys. Earth Planet. Inter. 156, 283-293. doi: 10.1016/j.pepi.2005.04.017

Larrasoaña, J. C., Roberts, A. P., and Rohling, E. J. (2008). Magnetic susceptibility of Eastern Mediterranean marine sediments as a proxy for Saharan dust supply? Mar. Geol. 254, 224-229. doi: 10.1016/j.margeo.2008.06.003

Larrasoaña, J. C., Roberts, A. P., and Rohling, E. J. (2013). Dynamics of green Sahara periods and their role in hominin evolution. PLOS ONE 8:e76514. doi: 10.1371/journal.pone.0076514

Larrasoaña, J. C., Roberts, A. P., Rohling, E. J., Winklhofer, M., and Wehausen, R. (2003a). Three million years of monsoon variability over the northern Sahara. Clim. Dyn. 21, 689-698. doi: 10.1007/s00382-003-0355-z

Larrasoaña, J. C., Roberts, A. P., Stoner, J. S., Richter, C., and Wehausen, R. (2003b). A new proxy for bottom-water ventilation in the Eastern Mediterranean based on diagenetically controlled magnetic properties of sapropel-bearing sediments, Palaeogeogr. Palaeoclimatol. Palaeoecol. 190, 221-242. doi: 10.1016/S0031-0182(02)00607-7

Lawrence, C. R., and Neff, J. C. (2009). The contemporary physical and chemical flux of aeolian dust: a synthesis of direct measurements of dust deposition. Chem. Geol. 267, 46-63. doi: 10.1016/j.chemgeo.2009.02.005

Lean, C. B., Hounslow, M. W., Vine, F. J., Harwood, G. M., Elvige, L., Fisk, K., et al. (1998). Magnetostratigraphy and sedimentary evolution of the late Miocene to 
early Pleistocene sediments, Quseir region, Egyptian Red Sea. Geophys. J. Int. 133, 435-450. doi: 10.1046/j.1365-246X.1998.00515.x

Lee, C., Armstrong, R. A., Cochran, J. K., Engel, A., Fowler, S. W., Goutx, M., et al. (2009). MedFlux: investigations of particle flux in the Twilight Zone. Deep Sea Res. II 56, 1363-1368. doi: 10.1016/j.dsr2.2008.12.003

Lézine, A., Hély, C., Grenier, C., Braconnot, P., and Krinner, G. (2011). Sahara and Sahel vulnerability to climate changes, lessons from Holocene hydrological data. Quat. Sci. Rev. 30, 3001-3012. doi: 10.1016/j.quascirev.2011.07.006

Liu, Q. S., Barrón, V., Torrent, J., Eeckhout, S. G., and Deng, C. (2008). Magnetism of intermediate hydromaghemite in the transformation of 2-line ferrihydrite into hematite and its palaeoenvironmental implications. J. Geophys. Res. 113, B01103. doi: 10.1029/2007JB005207

Liu, Q. S., Deng, C. L., Torrent, J., and Zhu, R. X. (2007a). Review of recent developments in mineral magnetism of the Chinese loess. Quat. Sci. Rev. 26, 368-385. doi: 10.1016/j.quascirev.2006.08.004

Liu, Q. S., Larrasoaña, J. C., Torrent, J., Roberts, A. P., Rohling, E. J., Liu, Z., et al. (2012b). New constraints on climate forcing and variability in the circum-Mediterrranean region from magnetic and geochemical observations of sapropels S1, S5 and S6. Palaeogeogr. Palaeoclimatol. Palaeoecol. 333-334, 1-12. doi: 10.1016/j.palaeo.2012.02.036

Liu, Q. S., Roberts, A. P., Larrasoaña, J. C., Banerjee, S. K., Guyodo, Y., Tauxe, L., et al. (2012a). Environmental magnetism: principles and applications. Rev. Geophys. 50, RG4002. doi: 10.1029/2012RG000393

Liu, Q. S., Roberts, A. P., Torrent, J., Horng, C. S., and Larrasoaña, J. C. (2007b). What do the HIRM and S-ratio really measure in environmental magnetism? Geochem. Geophys. Geosyst. 8, Q09011. doi: 10.1029/2007GC001717

Lotfy, H. I. (2011). Active concomitant counterclockwise rotation and northwards translation of Africa during the Albian-Campanian time: a paleomagnetic study on the Wadi Natash alkaline volcanic province (104-78 Ma), South Eastern Desert, Egypt. Palaeogeogr. Palaeoclimatol. Palaeoecol. 310, 176-190. doi: 10.1016/j.palaeo.2011.07.005

Lotfy, H. I., and van der Voo, R. (2007). Tropical northeast Africa in the middle-late Eocene: paleomagnetism of marine-mammal sites and basalts in the Fayum province, Egypt. J. Afr. Earth Sci. 47, 135-152. doi: 10.1016/j.jafrearsci.2006.12.005

Lourens, L. J., Wehausen, R., and Brumsack, H. J. (2003). Geological constraints on tidal dissipation and dynamical ellipticity of the Earth over the past three million years. Nature 409, 1029-1033. doi: 10.1038/35059062

Lyons, R., Oldfield, F., and Williams, E. (2010). Mineral magnetic properties of surface soils and sands across four North African transects and links to climatic gradients. Geochem. Geophys. Geosyst. 11, Q08023. doi: 10.1029/2010GC003183

Lyons, R., Oldfield, F., and Willams, E. (2012). The possible role of magnetic measurements in the discrimination of Sahara/Sahel dust sources. Earth Surf. Proc. Land. 37, 594-606. doi: 10.1002/esp.2268

Maher, B. A. (2011). The magnetic properties of Quaternary aeolian dusts and sediments, and their palaeoclimatic significance. Aeolian Res. 3, 87-144. doi: 10.1016/j.aeolia.2011.01.005

Maher, B. A., and Dennis, P. F. (2001). Evidence against dust-mediated control of glacial-interglacial changes in atmospheric $\mathrm{CO}_{2}$. Nature 411, 176-180. doi: $10.1038 / 35075543$

Maher, B. A., Karloukovski, V. V., and Mutch, T. J. (2004). High-field remanence properties of synthetic and natural submicrometre haematites and goethites: significance for environmental contexts. Earth Planet. Sci. Lett. 226, 491-505. doi: 10.1016/j.epsl.2004.05.042

Maher, B. A., Prospero, J., Mackie, D., Gaiero, D. M., Hesse, P. P., and Balkanski, Y. (2010). Global connections between aeolian dust, climate and ocean biogeochemistry at the present day and at the last glacial maximum. Earth Sci. Rev. 99, 61-97. doi: 10.1016/j.earscirev.2009.12.001

Mahowald, N. M., Muhs, D. R., Levis, S., Rasch, P. J., Yoshioka, M., Zender, C. S., et al. (2006). Changes in atmospheric mineral aerosols in response to climate: last glacial period, preindustrial, modern and doubled carbon dioxide climates. J. Geophys. Res. 111, D10202. doi: 10.1029/2005JD006653

Maley, J. (2000). Last Glacial Maximum lacustrine and fluviatile formations in the Tibesti and other Saharan mountains, and large-scale climatic teleconnections linked to the activity of the Subtropical Jet Stream. Global Planet. Change 26, 121-136. doi: 10.1016/S0921-8181(00)00039-4

Mattsson, J. O., and Nihlén, T. (1996). The transport of Saharan dust to southern Europe: a scenario. J. Arid Environ. 32, 111-119. doi: 10.1006/jare.1996.0011
McTainsh, G., and Strong, C. (2007). The role of dust in ecosystems. Geomorphology 89, 39-54. doi: 10.1016/j.geomorph.2006.07.028

Odah, H. (2004). Paleomagnetism of the Upper Cretaceous Bahariya Formation, Bahariya Oasis, Western Desert, Egypt. J. Appl. Geophys. 3, 177-187.

O'Hara, S. O., Clarke, M. L., and Elatrash, M. S. (2006). Field measurements of desert dust deposition in Libya. Atmos. Environ. 40, 3881-3897. doi: 10.1016/j.atmosenv.2006.02.020

Oldfield, F., Chiverell, R. C., Lyons, R., Williams, E., Shen, Z., Bristow, C., et al. (2014). Discriminating dusts and dust sources using magnetic properties and hematite-goethite ratios of surface materials and dust from North Africa, the Atlantic and Barbados. Aeol. Res. 13, 91-104. doi: 10.1016/j.aeolia.2014. 03.010

Passier, H. F., and Dekkers, M. J. (2002). Iron oxide formation in the active oxidation front above sapropel S1 in the eastern Mediterranean Sea as derived from low-temperature magnetism. Geophys. J. Int. 150, 230-240. doi: 10.1046/j.1365-246X.2002.01704.x

Passier, H. F., de Lange, G. J., and Dekkers, M. J. (2001). Magnetic properties and geochemistry of the active oxidation front and the youngest sapropel in the eastern Mediterranean Sea. Geophys. J. Int. 145, 604-614. doi: 10.1046/j.0956540x.2001.01394.x

Perrin, M., Saleh, A., and Alva-Valdivia, L. (2009). Cenozoic and Mesozoic basalts from Egypt: a preliminary survey with a view to paleointensity. Earth Planets Space 61, 51-60. doi: 10.1186/BF03352884

Peters, C., and Dekkers, M. J. (2003). Selected room temperature magnetic parameters as a function of mineralogy, concentration and grain size. Phys. Chem. Earth 28, 659-667. doi: 10.1016/S1474-7065(03)00120-7

Petit-Maire, N., and Guo, Z. (1997). Holocene paleoprecipitation over the presentday Sahara desert: implications for the future. Episodes 20, 232-234.

Poulton, S. W., Krom, M. D., and Raiswell, R. (2004). A revised scheme for the reactivity of iron (oxyhydr) oxide minerals towards dissolved sulfide. Geochim. Cosmochim. Acta 68, 3703-3715. doi: 10.1016/j.gca.2004.03.012

Prospero, J. M., Blades, E., Mathison, G., and Naidu, R. (2005). Interhemispheric transport of viable fungi and bacteria from Africa to the Caribbean with soil dust. Aerobiologia 21, 1-19. doi: 10.1007/s10453-004-5872-7

Prospero, J. M., Ginoux, P., Torres, O., Nicholson, S. E., and Gill, T. E. (2002). Environmental characterization of global sources of atmospheric soil dust identified with the Nimbus 7 Total Ozone Mapping Spectrometer (TOMS) absorbing aerosol product. Rev. Geophys. 40, 1002. doi: 10.1029/2000RG000095

Pye, K. (1989). "Processes of fine particle formation, dust source regions, and climatic changes," in Paleoclimatology and Paleometeorology; Modern and Past Patterns of Global Atmospheric Transport, eds M. Leinen and M. Sarnthein (Dordrecht: Kluwer Academic Pubs), 3-30. doi: 10.1007/978-94-0090995-3_1

Quinton, E. E., Dahms, D. E., and Geiss, C. E. (2011). Magnetic analyses of soils from the Wind River Range, Wyoming, constrain rates and pathways of magnetic enhancement for soils from semiarid climates. Geochem. Geophys. Geosyst. 12, Q07Z30. doi: 10.1029/2011GC003728

Reinholdsson, M., Snowball, I., Zillén, L., Lenz, C., and Conley, D. J. (2013). Magnetic enhancement of Baltic Sea sapropels by greigite magnetofossils. Earth Planet. Sci. Lett. 366, 137-150. doi: 10.1016/j.epsl.2013.01.029

Reischmann, T., Bachtadse, V., Kroner, A., and Layer, P. (1992). Geochronology and paleomagnetism of a late Proterozoic island-arc terrane from the Red Sea hills, Northeast Sudan. Earth Planet. Sci. Lett. 114, 1-15. doi: 10.1016/0012821X(92)90148-O

Roberts, A. P., Chang, L., Heslop, D., Florindo, F., and Larrasoaña, J. C. (2012). Searching for single domain magnetite in the 'pseudo-single-domain' sedimentary haystack: implications of biogenic magnetite preservation for sediment magnetism and relative paleointensity determinations. J. Geophys. Res. 117, B08104. doi: 10.1029/2012JB009412

Roberts, A. P., Rohling, E. J., Grant, K. M., Larrasoaña, J. C., and Liu, Q. S. (2011). Atmospheric dust variability from major global source regions over the last 500,000 years. Quat. Sci. Rev. 30, 3537-3541. doi: 10.1016/j.quascirev.2011.09.007

Roberts, A. P., Stoner, J. S., and Richter, C. (1999). Diagenetic magnetic enhancement of sapropels from the eastern Mediterranean Sea. Mar. Geol. 153, 103-116. doi: 10.1016/S0025-3227(98)00087-5

Rochette, P., Mathe, P. P., Esteban, L., Rakoto, H., Bouchez, J. L., Liu, Q. S., et al. (2005). Non-saturation of the defect moment of goethite and 
fine-grained hematite up to 57 Teslas. Geophys. Res. Lett. 32:L22309. doi: 10.1029/2005GL024196

Rohling, E. J., Grant, K., Hemleben, C., Kucera, M., Roberts, A. P., Schmeltzer, I., et al. (2008). New constraints on the timing of sea level fluctuations during early to middle marine isotope stage 3. Paleoceanography 23, PA3219. doi: 10.1029/2008PA001617

Rohling, E. J., Marino, G., and Grant, K. M. (2015). Mediterrranean climate and oceanography, and the periodic development of anoxic events (sapropels). Earth Sci. Rev. 143, 62-97. doi: 10.1016/j.earscirev.2015. 01.008

Scheuvens, D., Schütz, L., Kandler, K., Ebert, M., and Weinbruch, S. (2013). Bulk composition of northern African dust and its source sediments A compilation. Earth Sci. Rev. 116, 170-194. doi: 10.1016/j.earscirev.2012. 08.005

Schlüter, T. (2008). Geological Atlas of Africa. Berlin: Springer.

Schwertmann, U., and Taylor, R. M. (1989). "Iron oxides," in Minerals in Soil Environments, eds J. B. Dickson and S. B. Weed (Madison: Soil Society of America), 379-438.

Shao, Y., Wyrwoll, K. H., Chappell, A., Huang, J., Lin, Z., McTainsh, G. H., et al. (2011). Dust cycle: an emerging core theme in Earth system science. Aeol. Res. 2, 181-204. doi: 10.1016/j.aeolia.2011.02.001

Shinn, E. A., Smith, G. W., Prospero, J. M., Betzer, P., Hayes, M. L., Garrison, V., et al. (2000). African dust and the demise of Caribbean coral reefs. Geophys. Res. Lett. 27, 3029-3032. doi: 10.1029/2000GL011599

Smalley, I. J., Kumar, R., O'Hara, D., Jefferson, I. F., and Evans, R. D. (2005). The formation of silt material for terrestrial sediments: particularly loess and dust. Sediment. Geol. 179, 321-328. doi: 10.1016/j.sedgeo.2005. 06.011

Swezey, C. S. (2009). Cenozoic stratigraphy of the Sahara, Northern Africa. J. Afr. Earth Sci. 53, 89-121. doi: 10.1016/j.jafrearsci.2008.08.001

Tauxe, L. (2010). Essentials of Paleomagnetism. Berkeley: University of California Press.

Torrent, J., Barrón, V., and Liu, Q. S. (2006). Magnetic enhancement is linked to and precedes hematite formation in aerobic soil. Geophys. Res. Lett. 33, L02401. doi: 10.1029/2005GL024818

Trauth, M. H., Larrasoaña, J. C., and Mudelsee, M. (2009). Trends, rhythms and events in Plio-Pleistocene African climate. Quat. Sci. Rev. 28, 399-411. doi: 10.1016/j.quascirev.2008.11.003

Van Santvoort, P. J. M., De Lange, G. J., Langereis, C. G., and Dekkers, M. J. (1997). Geochemical and paleomagnetic evidence for the occurrence of 'missing' sapropels in eastern Mediterranean sediments. Paleoceanography 12, 773-786. doi: 10.1029/97PA01351
Varga, G., Üjvári, G., and Kovács, J. (2014). Spatiotemporal patterns of Saharan dust outbreaks in the Mediterranean Basin. Aeol. Res. 15, 151-160. doi: 10.1016/j.aeolia.2014.06.005

Wehausen, R., and Brumsack, H. J. (1999). Cyclic variations in the chemical composition of Eastern Mediterranean Plocene sediments: a key for understanding sapropel formation. Mar. Geol. 153, 161-176. doi: 10.1016/S0025-3227(98)00083-8

Wehausen, R., and Brumsack, H. J. (2000). Chemical cycles in Pliocene sapropelbearing and sapropel-barren eastern Mediterranean sediments. Palaeogeogr. Palaeoclimatol. Palaeoecol. 158, 325-352. doi: 10.1016/S0031-0182(00)0 0057-2

Yaalon, D. H., and Ganor, E. (1979). "East Mediterranean trajectories of dust carrying storms from the Sahara and Sinai," in Saharan Dust: Mobilization, Transport, Deposition, ed C. Morales (Chichester: Wiley), 187-193.

Yamazaki, T. (2009). Environmental magnetism of Pleistocene sediments in the North Pacific and Ontong-Java Plaeau: temporal variations of detrital and biogenic components. Geochem. Geophys. Geosyst. 10, Q07ZQ04. doi: $10.1029 / 2009 \mathrm{GC} 002413$

Yamazaki, T. (2012). Paleoposition of the Intertropical Convergence Zone in the eastern Pacific inferred from glacial-interglacial changes in terrigenous and biogenic magnetic mineral fractions. Geology 40, 151-154. doi: $10.1130 /$ G32646.1

Yamazaki, T., and Ioka, N. (1997). Environmental rock-magnetism of pelagic clay: implications for Asian eolian input to the North Pacific since the Pliocene. Paleoceanography 12, 111-124. doi: 10.1029/96PA02757

Zhao, Y., Colin, C., Liu, Z., Paterne, M., Siani, G., and Xie, X. (2012). Reconstructing precipitation changes in northeastern Africa during the Quaternary by clay mineralogical and geochemical investigations of Nile deep-sea fan sediments. Quat. Sci. Rev. 57, 58-70. doi: 10.1016/j.quascirev.2012.10.009

Conflict of Interest Statement: The authors declare that the research was conducted in the absence of any commercial or financial relationships that could be construed as a potential conflict of interest.

Copyright (ङ 2015 Larrasoaña, Roberts, Liu, Lyons, Oldfield, Rohling and Heslop. This is an open-access article distributed under the terms of the Creative Commons Attribution License (CC BY). The use, distribution or reproduction in other forums is permitted, provided the original author(s) or licensor are credited and that the original publication in this journal is cited, in accordance with accepted academic practice. No use, distribution or reproduction is permitted which does not comply with these terms. 